Original Research

\title{
Development of an Efficient Bi-Functional Catalyst made of a Novel Hybrid Material for Rechargeable Zn-Air Battery
}

\author{
Shiping Wang, Georg Bendt, Stephan Schulz *
}

Faculty of Chemistry and Center for Nanolntegration (CENIDE), University of Duisburg-Essen, Essen 45117, Germany; E-Mails: 21006210@zju.edu.cn; georg.bendt@uni-due.de; stephan.schulz@unidue.de

* Correspondence: Stephan Schulz; E-Mail: stephan.schulz@uni-due.de

Academic Editor: Atsushi Ohtaka

Special Issue: Polymer-Supported Transition-Metal Catalysts

$\begin{array}{ll}\text { Catalysis Research } & \text { Received: May 24, } 2021 \\ \text { 2021, volume 1, issue 3 } & \text { Accepted: July 05, } 2021 \\ \text { doi:10.21926/cr.2103001 } & \text { Published: July 16, } 2021\end{array}$

\begin{abstract}
One-pot synthesis of mesoporous hybrid material consisting of $\mathrm{Mn}-\mathrm{Co} / \mathrm{CoO}$ nanoparticles encapsulated in an $\mathrm{N}$-doped graphene shell decorated with $\mathrm{Mo}_{2} \mathrm{C}$ nanoparticles $\left(\mathrm{Mo}_{2} \mathrm{C}-\right.$ $\mathrm{NC@Mn-Co/CoO)} \mathrm{was} \mathrm{reported.} \mathrm{The} \mathrm{Mn}$ and Mo components synergistically refined the graphitized carbons due to the interactions with $\mathrm{N}$ and $\mathrm{C}$ atoms while promoting the stability of the $\mathrm{Co} / \mathrm{CoO}$ nanoparticles. These components exhibited a beneficial effect on the dispersion of the active metal/metal oxide nanoparticles and the formation of a mesoporous structure under high-temperature conditions, which together led to optimized oxygen adsorption/desorption capabilities as well as mass transport properties. The hybrid material showed high bifunctional performance for both oxygen evolution reaction (OER) and oxygen reduction reaction (ORR), as well as promising catalytic properties as the air electrode in a zinc-air battery, featuring superior long-term cycle stability comparable to that of $\mathrm{Pt}-\mathrm{C} / \mathrm{RuO}_{2}$ materials.
\end{abstract}

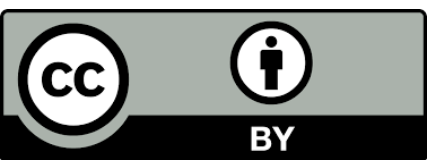

(C) 2021 by the author. This is an open access article distributed under the conditions of the Creative Commons by Attribution License, which permits unrestricted use, distribution, and reproduction in any medium or format, provided the original work is correctly cited. 


\section{Keywords}

Bi-functional electrocatalyst; core-shell nanoparticles; N-doped graphene; transition metals; Zn-air battery

\section{Introduction}

The pursuit of renewable and green energy has prompted the development of diverse energy devices such as metal-air batteries and fuel cells [1-4]. To achieve efficient energy conversion and storage, catalysts play a significant role in overcoming the sluggish kinetics of both oxygen reduction reaction (ORR) and oxygen evolution reaction (OER) [5-11]. Noble metals often assist as highly active ORR and OER catalysts; however, they are low in abundance. Similarly, Pt-carbon hybrid materials (Pt-C) are among the best ORR electrocatalysts, yet they show poor activity in $\mathrm{OER}$, and while Ru/Ir oxides were proven highly efficient in OER, they are conversely very poor ORR catalysts [12-15]. Comparable findings were reported for nonprecious catalysts such as earthabundant transition metals (e.g., $\mathrm{Mn}, \mathrm{Fe}, \mathrm{Co}$, and $\mathrm{Ni}$ ), solely active in ORR [5, 16-18] or OER [19-22]. On the contrary, bimetallic composite materials such as $\mathrm{Mn}$ and Co oxides were found to be excellent bifunctional catalysts for both ORR and OER [23-34], while multi-metal oxides containing $\mathrm{Mn}, \mathrm{Fe}, \mathrm{Co}$, and $\mathrm{Ni}$ often outperformed sole metal oxides [35-39]. These findings point towards a synergistic modulation of the electronic properties and intermediates' adsorption energies.

The combination of transition metals (TMs) with carbon-based materials, such as graphene and carbon nanotubes (CNTs), also produced highly efficient catalysts with high electric conductivities and superior stability in various electrolytes [40-53]. Studies revealed that well-structured graphene materials are less efficient catalysts due to their inert and low polar surface, whereas high defect carbon-based materials have superior electrocatalytic properties [54-56]. Porous graphitic carbon materials containing $\mathrm{MnO} / \mathrm{Co}$ heterointerfaces were recently prepared using hydrothermal-calcination approaches [57]. Interestingly, in situ generated Co nanocrystals were found to improve the OER activity and promote the formation of robust graphitic carbon, making it an efficient air cathode for rechargeable Zn-air batteries [58-62]. Unfortunately, the stabilization of defect-rich carbon-based materials under high-temperature synthetic conditions (thermodynamic control) is rather difficult [24]. However, recent reports showed the promising effect of Mo carbides on the stabilization of carbon defects, which most likely results from the strong interactions between Mo and carbon atoms [63].

Modification of nonpolar and unreactive carbon surfaces by adding functional organic groups (e.g., carboxylic groups) or doping with heteroatoms such as nitrogen was found to improve the metal-binding strength as well as the dispersion of metal catalysts on the carbon supports [64-69]. Unfortunately, conventional impregnation and precipitation methods, which are typically performed at relatively low reaction temperatures for the synthesis of such hybrid materials, do not favor heteroatom doping [70-72]. Pyrolysis of TMs-coordination compounds such as metalorganic frameworks (MOFs) and metal-coordination polymers is an alternative strategy for synthesizing metal-carbon composites [73-77]. However, similar to defect-rich carbon materials, heteroatoms and functional groups are unstable in the composite materials under hightemperature conditions [78]. In addition, high-temperature processes often favor the sintering of 
metal nanoparticles as well as the graphitization of carbon, known to be catalyzed by metals such as $\mathrm{Fe}, \mathrm{Co}$, and $\mathrm{Ni}$. Both effects are disadvantageous for the synthesis of finely dispersed active metal components on mesoporous structure supports, which should promote OER and ORR processes by facile mass transport.

Herein, we report a novel one-pot synthesis of $\mathrm{Mn}$-doped $\mathrm{Co} / \mathrm{CoO}$ nanoparticles encapsulated in a highly thermally stable mesoporous hybrid material consisting of $\mathrm{N}$-doped graphene with $\mathrm{Mo}_{2} \mathrm{C}$ nanoparticles $\left(\mathrm{Mo}_{2} \mathrm{C}-\mathrm{NC} @ \mathrm{Mn}-\mathrm{Co} / \mathrm{CoO}\right)$. This material was synthesized from the multicomponent precursors of citric acid-treated melamine, and a tailored metal coordination polymer consisting of $\mathrm{Mn}$-Co oxide coordinated with a molybdic acid-bridged melamineformaldehyde (MF) resin. The citric acid-treated melamine (CM) helps in forming a thin carbonnitrogen film around the metal oxides, which serves as a soft template to support the dispersion of the active components and inhibit their coalescence into larger agglomerates during the hightemperature sintering process. The resulting hybrid material was found highly efficient for both OER and ORR reactions, while its performance as an electrocatalyst on the air electrode of a $\mathrm{Zn}$-air battery was comparable to that of recently developed catalysts and precious $\mathrm{Pt}-\mathrm{C} / \mathrm{RuO}_{2}$.

\section{Results and Discussion}

\subsection{Precursor Synthesis and Characterization}

$\mathrm{Mn}$-Co/CoO nanoparticles encapsulated in mesoporous $\mathrm{N}$-doped graphene decorated with $\mathrm{Mo}_{2} \mathrm{C}$ nanoparticles ( $\mathrm{Mo}_{2} \mathrm{C}-\mathrm{NC} @ \mathrm{Mn}-\mathrm{Co} / \mathrm{CoO}$ ) were synthesized by pyrolysis of $\mathrm{Mn}$-Co oxide nanoparticles coated with molybdic acid-bridged $\mathrm{MF}$ resin in the presence of citric acid-treated melamine (CM) at $800^{\circ} \mathrm{C}$ for $1 \mathrm{~h}$ under Ar flow (Scheme 1).

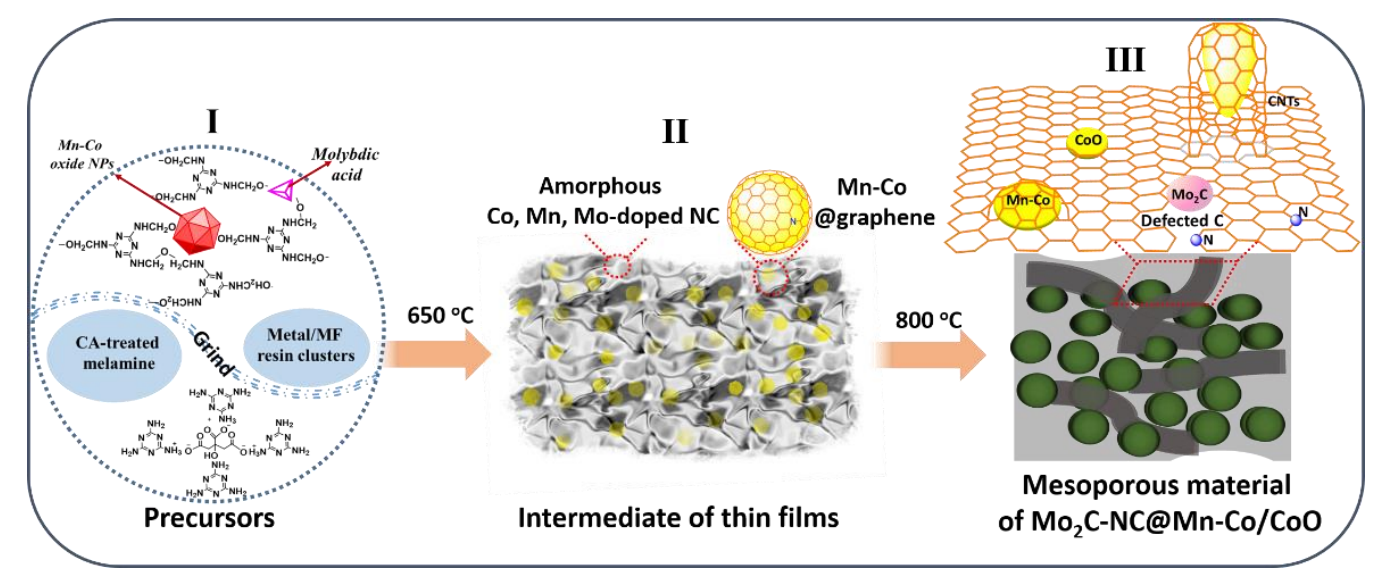

Scheme 1 Illustration of the synthetic protocol of the Mo $2 \mathrm{C}-\mathrm{NC} @ \mathrm{Mn}-\mathrm{Co} / \mathrm{CoO}$ hybrid material.

A composite material was also prepared as a control sample from a solid mixture containing Co, $\mathrm{Mn}$, and Mo sources. Although melamine is a low-cost and sustainable source of carbon with a high amount of nitrogen (67 wt\%), its low thermal stability poses a disadvantage to the hightemperature synthesis of carbon materials [79-81]. While citric acid-treated melamine has improved thermal stability (Figure S1), it was used as an alternative source for the synthesis of $\mathrm{N}$ doped carbon materials. In addition, a customized metal-coordination polymer with high thermal 
stability was used as the metal precursor, prepared by hydrothermal treatment of $\mathrm{Mn}$-Co oxide nanoparticles in a solution containing a mixture of melamine, formaldehyde, and molybdic acid. The resulting metal precursor consisted of $\mathrm{Mn}$-Co oxide nanoparticles coordinated with amorphous melamine-formaldehyde (MF) resin (Figure S2 \&Figure S3). The TEM and EDX elemental mappings confirmed that the $\mathrm{Mn}$-Co oxide nanoparticles were encapsulated by the MF resin, while Mo was uniformly distributed in the metal-coordinated polymer (Figure S4 \& Figure S5) (Scheme 1 (I)).

\subsection{Synthesis and Characterization of Hybrid Materials}

To prepare sample $\mathrm{E}\left(\mathrm{Mo}_{2} \mathrm{C}-\mathrm{NC} @ \mathrm{Mn}-\mathrm{Co} / \mathrm{CoO}\right)$, the precursor of metal/MF coordination polymer was ground with the citric acid-treated melamine and pyrolyzed at $800{ }^{\circ} \mathrm{C}$ to generate the mesoporous $\mathrm{Mo}_{2} \mathrm{C}-\mathrm{NC} @ \mathrm{Mn}-\mathrm{Co} / \mathrm{CoO}$ material as shown in Scheme 1. The XRD patterns (Figure 1A) confirmed the formation of Co crystals composited with $\mathrm{Mo}_{2} \mathrm{C}$ and graphite, while an additional small peak at around $42.5 \mathrm{deg}$ pointed to CoO. In comparison to sample A (NC@Co), the peaks corresponding to Co crystals shifted to lower angles, possibly due to the Mn doping. Raman spectra (Figure $1 \mathrm{~B}$ ) showed that the sample had an $\mathrm{I}_{\mathrm{D}} / \mathrm{I}_{\mathrm{G}}$ value of 1.06 , further indicating the graphitization of the carbons.
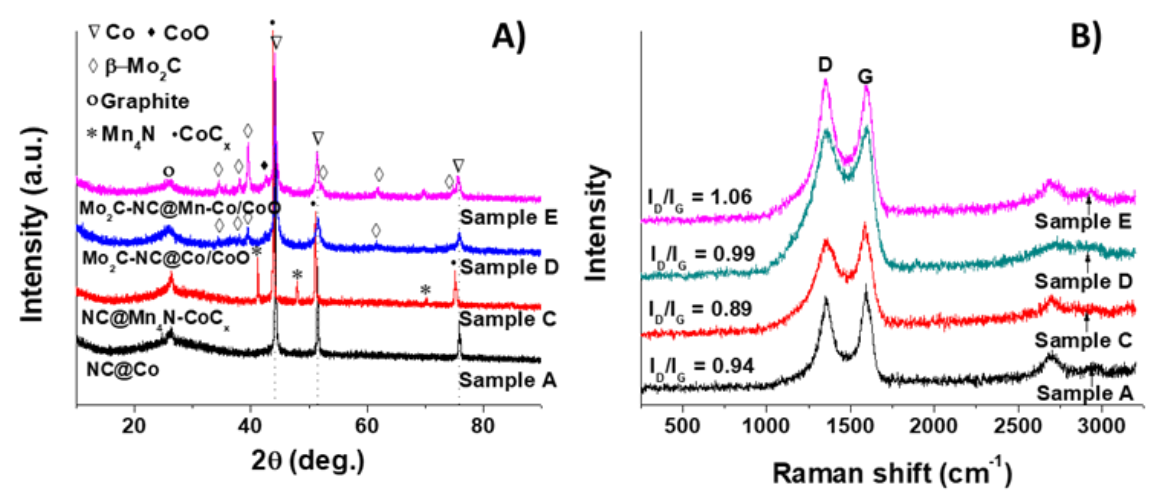

Figure 1 A) The XRD patterns and B) Raman spectra of different samples.

SEM images (Figures S6A-B) revealed flake-like morphologies as well as carbon nanotubes measuring $30 \mathrm{~nm}$ in width (Figure S6C). According to the TEM studies (Figures 2A-B) and elemental EDX mappings (Figures $3 \mathrm{~A}-\mathrm{C}$ ), the nanoparticles were mainly $\mathrm{Mn}$-doped Co with an average diameter of $20 \mathrm{~nm}$ and were encapsulated in graphene layers that contained $\mathrm{CoO}$ and $\mathrm{Mo}_{2} \mathrm{C}$ nanoparticles (Figures 2C-D and Figures S6D-E). Further, the $\mathrm{N}_{2}$ adsorption-desorption measurements (Figure S7) confirmed the existence of mesopores in the material, formed mainly from the stacking of different nanoparticles. The atomic lattices determined from the HR-TEM images (Figures 2D1-3) further confirmed the presence of crystalline $\mathrm{Co}, \mathrm{CoO}$, and $\mathrm{Mo}_{2} \mathrm{C}$ nanoparticles, as shown in the XRD measurements. The EDX mappings (Figure 3D) also confirmed a uniform existence of nitrogen $(\mathrm{N})$ around these nanoparticles, which possibly originated from the $\mathrm{N}$-doping of the carbon atoms. 

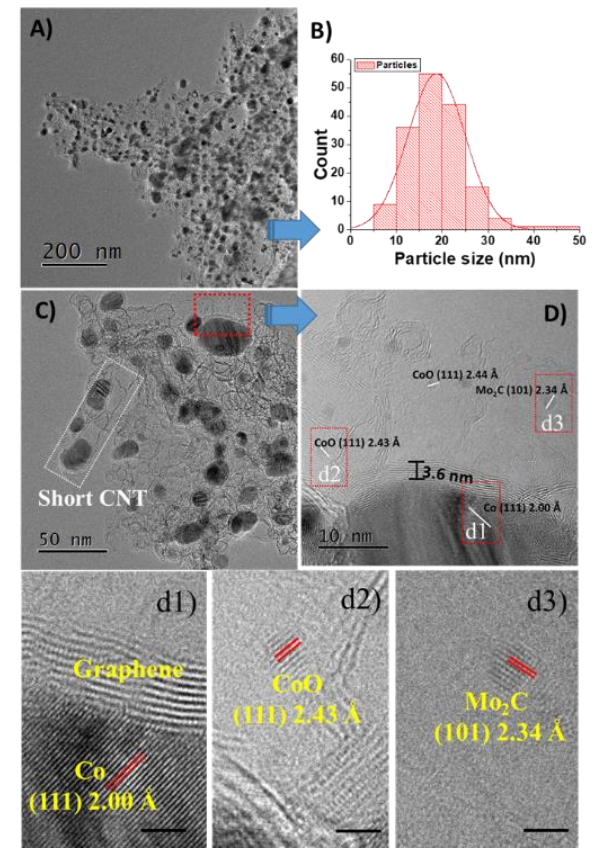

Figure 2 A) TEM image and B) particle width distribution of the $\mathrm{Mo}_{2} \mathrm{C}-\mathrm{NC} @ \mathrm{Mn}-\mathrm{Co} / \mathrm{CoO}$ material of sample E. C) Higher resolution TEM image of sample E. D) HR-TEM images showing -the atomic lattice for different crystals in the material. The scale bar in the images (d1-d3) is $2 \mathrm{~nm}$.

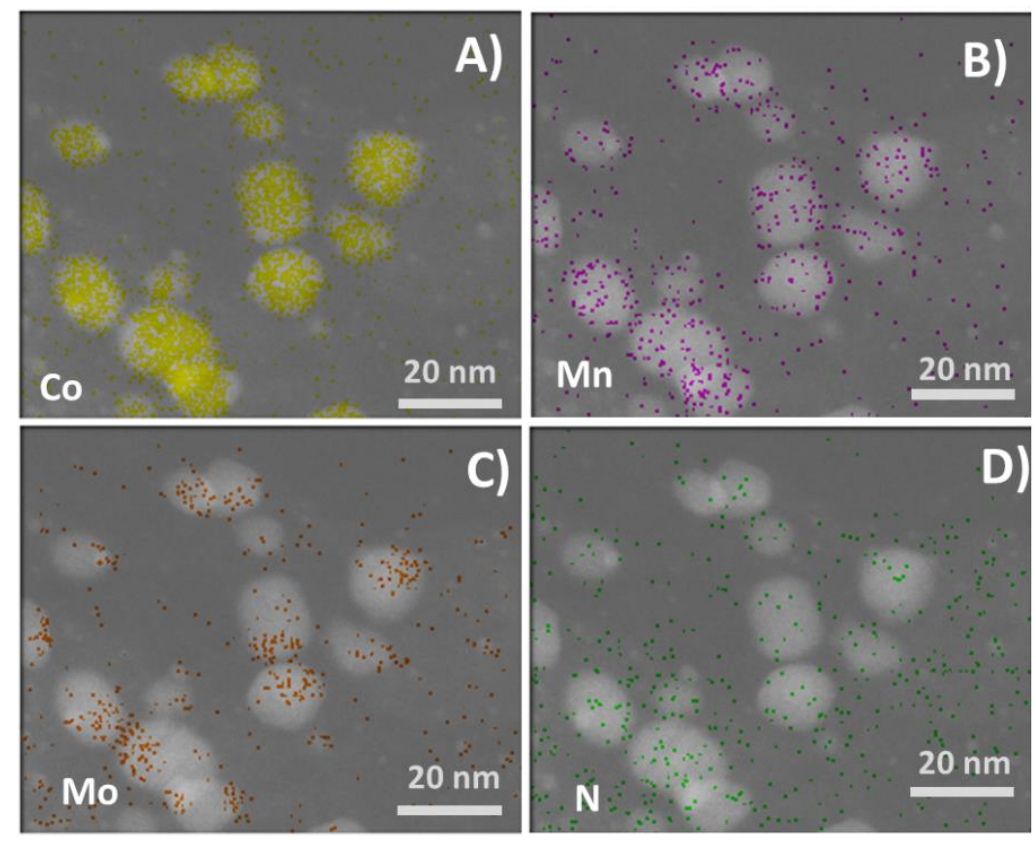

Figure 3 STEM images combined with the elemental mappings of the $\mathrm{Mo}_{2} \mathrm{C}-\mathrm{NC} @ \mathrm{Mn}$ $\mathrm{Co} / \mathrm{CoO}$ material for sample $\mathrm{E}$.

To investigate the formation process (Scheme 1), samples F (CM-Pre-500) and G (CM-Pre-650) were prepared by treating the same precursors at $500{ }^{\circ} \mathrm{C}$ and $650{ }^{\circ} \mathrm{C}$, respectively. The resulting compositions and morphologies were then studied in detail. The XRD patterns proved that the initial composite precursor consisted of Mn-Co oxide composed of amorphous carbon (Figure S8). 
After heating the mixture at $500{ }^{\circ} \mathrm{C}$ for $1 \mathrm{~h}$, the peaks corresponding to the $\mathrm{Mn}$-Co oxide almost completely disappeared while only one broad peak of the amorphous carbon (Figure S8, sample F) was present. After increasing the calcination temperature to $650{ }^{\circ} \mathrm{C}$, new peaks corresponding to metallic Co started to appear (Figure S8, sample G). At a higher calcination temperature of $800^{\circ} \mathrm{C}$, the intensity of the peaks corresponding to metallic Co increased sharply, while additional peaks due to the formation of crystalline $\mathrm{Mo}_{2} \mathrm{C}$ and $\mathrm{CoO}$ were also detected (Figure S8, sample E). The TEM images (Figure S9A) revealed that the composite precursor had an undefined morphology, in which the $\mathrm{Mn}$-Co oxide particles were embedded in the amorphous carbon. After calcinating the mixture at $500{ }^{\circ} \mathrm{C}$ (sample $\mathrm{F}$ ), the product was obtained as thin films (Figure S9B). Besides, based on the HR-TEM analysis, no crystalline domains were observed (Figure S9C), consistent with the PXRD analysis. A further increase in the calcination temperature to $650{ }^{\circ} \mathrm{C}$ (sample $\mathrm{G}$ ) yielded a porous flake-like morphology with dispersed nanoparticles ( 10 nm) embedded in carbon (Figure S9D-G, Scheme 1 (II)). In agreement with the PXRD, the STEM (Figure S10A) and EDX analyses (Figures S10B-G) indicated that these nanoparticles were mainly consisted of metallic Co nanoparticles with $\mathrm{Mn}$ dopant, while the isolated area of the flakes was nitrogen-doped carbon (NC) with uniformly distributed Mo. Finally, the calcination of sample $\mathrm{E}$ at $800{ }^{\circ} \mathrm{C}$ resulted in the desired $\mathrm{Mo}_{2} \mathrm{C}-\mathrm{NC} @ M n-\mathrm{Co} / \mathrm{CoO}$ material (Scheme 1 (III)).

Samples H (Pre-500), I (Pre-800), J (NC), K (Mix-500), L (control sample), and M (Mix-800) were prepared to further analyze the effects of the CA-treated melamine and the metal/MF coordination polymer on the synthesis process (Table 1). In the absence of CA-treated melamine, samples $\mathrm{H}$ and I were synthesized from the $\mathrm{Mn}$-Co oxide/MF coordination polymer at $500{ }^{\circ} \mathrm{C}$ and $800^{\circ} \mathrm{C}$, respectively. In contrast to the thin-film structure of sample $\mathrm{F}$, prepared in the presence of CA-treated melamine at $500{ }^{\circ} \mathrm{C}$, sample $\mathrm{H}$ consisted of stacked nanoparticles (Figures S11A-B). In the case of sample I, prepared at $800{ }^{\circ} \mathrm{C}$, TEM and EDX elemental mappings (Figures S11C-H) revealed that it consisted of heavily aggregated particles with an average particle size larger than $100 \mathrm{~nm}$, much larger than the nanoparticles $(\sim 20 \mathrm{~nm})$ formed in sample E. Meanwhile, the products directly prepared from CA-treated melamine at $800{ }^{\circ} \mathrm{C}$ (sample J) were porous graphene (Figure S12). These results indicated that the CA-treated melamine assisted in the formation of an intermediate thin-film in sample $F$, which then served as a soft template for the dispersion of nanoparticles in the final sample $\mathrm{E}$. Aside from samples $\mathrm{E}-\mathrm{J}$, samples $\mathrm{K}$ and $\mathrm{M}$ were synthesized from ammonium molybdate, $\mathrm{Co}$ (II) acetate tetrahydrate, and $\mathrm{Mn}$ (II) acetate tetrahydrate as metal precursors instead of the metal/MF coordination polymer (Table S1). At low calcination temperature $\left(500^{\circ} \mathrm{C}\right.$ ), sample $\mathrm{K}$ had uniformly dispersed $\mathrm{Co}, \mathrm{Mn}$, and Mo within the $\mathrm{N}$ - $\mathrm{C}$ thin film (Figure S13-14), whereas the calcination of sample $\mathrm{M}$ at $800{ }^{\circ} \mathrm{C}$ yielded $\mathrm{Mo}_{2} \mathrm{C}$ nanoparticles and $\mathrm{Mn}-\mathrm{Co} / \mathrm{CoO}$ particles much larger than the particles observed in $\mathrm{Mo}_{2} \mathrm{C}-\mathrm{NC} @ \mathrm{Mn}-\mathrm{Co} / \mathrm{CoO}$ material of sample E (Figures S15-17). In this case, the metal/MF resin composite precursor played an important role in suppressing the sintering effect and promoting the dispersion of nanoparticles during the synthesis process.

Table 1 Overview of samples with their formulae and synthesis temperature. Further details are given in Table S1.

\begin{tabular}{ccc}
\hline Samples & Names & $\mathrm{T}\left[{ }^{\circ} \mathrm{C}\right]$ \\
\hline $\mathbf{A}$ & NC@Co & 800 \\
\hline
\end{tabular}




\begin{tabular}{ccc}
\hline B & $\mathrm{NC}-\mathrm{Mn}_{7} \mathrm{C}_{3}$ & 800 \\
C & $\mathrm{NC} @ \mathrm{Mn}_{4}{ }_{4}-\mathrm{CoC} \mathrm{C}_{\mathrm{x}}$ & 800 \\
$\mathbf{D}$ & $\mathrm{Mo}_{2} \mathrm{C}-\mathrm{NC} @ \mathrm{Co} / \mathrm{CoO}$ & 800 \\
E & $\mathrm{Mo}_{2} \mathrm{C}-\mathrm{NC} @ \mathrm{Mn}-\mathrm{Co} / \mathrm{CoO}$ & 800 \\
F & $\mathrm{CM}-\mathrm{Pre}-500$ & 500 \\
G & $\mathrm{CM}-\mathrm{Pre}-650$ & 650 \\
H & Pre-500 & 500 \\
I & Pre-800 & 800 \\
J & $\mathrm{NC}$ & 800 \\
K & $\mathrm{Mix}-500$ & 500 \\
M & Control sample (Mix-800) & 800 \\
N & $\mathrm{NC}-\mathrm{Mo}_{2} \mathrm{C}$ & 800 \\
\hline
\end{tabular}

Note: "NC" refers to N-doped carbon, "CM" refers to citric acid-treated melamine, "Pre" refers to the metal-coordination polymer precursor.

To determine the effect of $\mathrm{Mn}$ and $\mathrm{Mo}$ on the formation of the composite material, a series of samples A (NC@Co), B (NC-Mn $\left.\mathrm{C}_{3}\right), \mathrm{C}\left(\mathrm{NC} @ \mathrm{Mn}_{4} \mathrm{~N}-\mathrm{Co} \mathrm{C}_{\mathrm{x}}\right), \mathrm{D}\left(\mathrm{Mo}_{2} \mathrm{C}-\mathrm{NC} @ \mathrm{Co} / \mathrm{CoO}\right)$, and $\mathrm{E}\left(\mathrm{Mo}_{2} \mathrm{C}-\right.$ $\mathrm{NC@Mn-Co/CoO)} \mathrm{prepared} \mathrm{from} \mathrm{precursors} \mathrm{with} \mathrm{varying} \mathrm{amounts} \mathrm{of} \mathrm{metals} \mathrm{(Co,} \mathrm{Mn,} \mathrm{Mo)} \mathrm{was}$ closely investigated (Table S1). The bulk contents of the different elements in the final samples after calcination are listed in Table S2. In sample E ( $\left.\mathrm{Mo}_{2} \mathrm{C}-\mathrm{NC} @ \mathrm{Mn}-\mathrm{Co} / \mathrm{CoO}\right)$, for example, the amount of $\mathrm{Mn}$ (2.51 wt.\%) and Mo (10.14 wt.\%) was much less than that of Co (35.00 wt.\%). Sample C (NC@Mn ${ }_{4} \mathrm{~N}-\mathrm{CoC}_{\mathrm{x}}$ ), prepared in the absence of Mo, contained 39.40 wt.\% Co and 10.58 wt.\% $\mathrm{Mn}$, whereas sample D ( $\left.\mathrm{Mo}_{2} \mathrm{C}-\mathrm{NC} @ \mathrm{Co} / \mathrm{CoO}\right)$, prepared in the absence of $\mathrm{Mn}$, had 37.73 wt.\% Co and 13.37 wt.\% Mo. Although the Co contents in samples $C$ and $D$ were relatively close to each other, a slightly higher amount (43.56 wt.\% Co) was observed in sample A (NC@Co), prepared in the absence of both $\mathrm{Mo}$ and $\mathrm{Mn}$. Interestingly, the $\mathrm{N}$ content in $\mathrm{NC@Co} \mathrm{(0.70wt. \% ),} \mathrm{Mo}_{2} \mathrm{C}$ $\mathrm{NC@Mn-Co/CoO} \mathrm{(0.38wt. \% ),} \mathrm{and} \mathrm{NC@Mn}{ }_{4} \mathrm{~N}-\mathrm{CoC}_{x}$ (0.17 wt.\%) decreased with the increasing amount of $\mathrm{Mn}$. This indicated that the $\mathrm{Mn}$ component in these composite materials favored the removal of $\mathrm{N}$ heteroatoms.

Similar to sample $\mathrm{E}$, the PXRD patterns (Figure $1 \mathrm{~A}$ ) showed that sample $\mathrm{D}$ consisted of $\mathrm{Mo}_{2} \mathrm{C}$ and metallic Co with some amount of $\mathrm{CoO}$. While no $\mathrm{CoO}$ was found in the Mo-free NC@Mn ${ }_{4} \mathrm{~N}$ $\mathrm{CoC}_{\mathrm{x}}$ (sample C) and NC@Co (sample A), we concluded that the composited Mo was critical for the formation of oxidized Co. The formation of $M n$ nitrides $\left(M n_{4} N\right)$ and Co carbides $\left(C_{0} C_{x}\right)$ in the sample NC@Mn${ }_{4} \mathrm{~N}-\mathrm{CoC}_{x}$ suggested that the removal of the $\mathrm{N}$ atoms from the carbons by $\mathrm{Mn}$ nitrides rather promoted the interaction between $\mathrm{Co}$ and carbons. In comparison to sample $\mathrm{A}$ ( $\mathrm{NC@Co)} \mathrm{without} \mathrm{Mn}$, the peaks corresponding to the Co crystal in samples $\mathrm{Mo}_{2} \mathrm{C}-\mathrm{NC} @ \mathrm{Mn}$ $\mathrm{Co} / \mathrm{CoO}$ and $\mathrm{NC@Mn}{ }_{4} \mathrm{~N}-\mathrm{CoC}_{x}$ shifted to lower angles, possibly due to the $\mathrm{Mn}$ doping. As mentioned in previous reports, $\mathrm{Mn}$ doping has the potential to improve the activity of $\mathrm{Co} / \mathrm{CoO}$ nanoparticles in composite materials [82-84]. The graphite peak was observed in all the samples; however, the peak width at half-height of the sample $\mathrm{Mo}_{2} \mathrm{C}-\mathrm{NC} @ \mathrm{Mn}-\mathrm{Co} / \mathrm{CoO}$ (2.18) was larger than that of $\mathrm{NC@Mn}{ }_{4} \mathrm{~N}-\mathrm{CoC}_{\mathrm{x}}(0.88)$ and $\mathrm{NC@Co} \mathrm{(1.18),} \mathrm{and} \mathrm{was} \mathrm{smaller} \mathrm{than} \mathrm{that} \mathrm{of} \mathrm{sample} \mathrm{Mo}_{2} \mathrm{C}$ NC@Co/CoO (3.62) without Mn. This suggested that Mn promoted the formation of crystalline graphite, which could be inversely hindered by the formation of Mo carbides. Moreover, the presence of $\mathrm{Mn}$ in sample $\mathrm{Mo}_{2} \mathrm{C}-\mathrm{NC} @ \mathrm{Mn}-\mathrm{Co} / \mathrm{CoO}$ facilitated the formation of $\mathrm{Mo}_{2} \mathrm{C}$ crystals, 
confirmed by the stronger signal intensity compared to the sample $\mathrm{Mo}_{2} \mathrm{C}-\mathrm{NC} @ \mathrm{Co} / \mathrm{CoO}$ without $\mathrm{Mn}$. The Raman spectra (Figure 1B) showed that sample $\mathrm{NC@Mn}{ }_{4} \mathrm{~N}-\mathrm{CoC}_{\mathrm{x}}$ had a lower $\mathrm{I}_{\mathrm{D}} / \mathrm{I}_{\mathrm{G}}$ value (0.89) than NC@Co (0.94), thereby indicating an improved degree of graphitization. The highest $\mathrm{I}_{\mathrm{D}} / \mathrm{I}_{\mathrm{G}}$ value (1.06) was found in the case of sample $\mathrm{Mo}_{2} \mathrm{C}-\mathrm{NC} @ \mathrm{Mn}-\mathrm{Co} / \mathrm{CoO}$. It was even higher than the value (0.99) observed for sample $\mathrm{Mo}_{2} \mathrm{C}-\mathrm{NC} @ \mathrm{Co} / \mathrm{CoO}$ that contained a higher Mo content. This could be attributed to the positive effect of $\mathrm{Mn}$ on the formation of $\mathrm{Mo}_{2} \mathrm{C}$ crystals, promoting the formation of defected carbons on the surface. Overall, the present study proved that the graphitized carbons in the $\mathrm{Mo}_{2} \mathrm{C}-\mathrm{NC} @ \mathrm{Mn}-\mathrm{Co} / \mathrm{CoO}$ material had the highest degree of defects, which would ultimately generate more active sites in favor of the ORR [54-56, 85].

The presence of $\mathrm{Mn}$ and $\mathrm{Mo}$ also influences the morphology of the resulting material. As mentioned before, sample $\mathrm{E}$ ( $\left.\mathrm{Mo}_{2} \mathrm{C}-\mathrm{NC} @ \mathrm{Mn}-\mathrm{Co} / \mathrm{CoO}\right)$ consisted of $\mathrm{N}$-doped graphene encapsulated $\mathrm{Mn}-\mathrm{Co} / \mathrm{CoO}$ nanoparticles $(\sim 20 \mathrm{~nm})$ and some carbon nanotubes $(\sim 30 \mathrm{~nm})$. Highresolution transmission electron microscopy (HR-TEM) images (Figures 2D and d1, Figures S6D-E) also revealed the formation of very thin carbon layers. Nanoparticles smaller than $20 \mathrm{~nm}$ in diameter had carbon coatings less than $1 \mathrm{~nm}$ thick; however, the thickness of these coatings improved in larger nanoparticles (Figures S6D-E). According to HR-TEM analysis (Figure 2D and Figures S6D-E) and EDX elemental mappings (Figure 3), the small $\mathrm{Mo}_{2} \mathrm{C}$ clusters were homogeneously dispersed in the graphitized carbons, while some were adjacent to the Co nanoparticles. Similarly, the $\mathrm{CoO}$ nanoparticles were either present at the edge of the metallic Co nanoparticles or decorated in the isolated carbons. In contrast, stacked $\mathrm{Co} / \mathrm{CoO}$ nanoparticles free of carbon nanotubes were formed in the absence of $\mathrm{Mn}$ (sample D, Mo $2 \mathrm{C}-\mathrm{NC} @ \mathrm{Co} / \mathrm{CoO}$ ). According to SEM studies (Figures S18A-B), the nanoparticles had an average diameter of $40 \mathrm{~nm}$ and were embedded in the carbon material decorated with small Mo clusters (Figures S18C-F and Figure S19). Samples A (NC@Co) and C (NC@Mn 4 N-CoC ) contained much larger bamboo-like 200 $\mathrm{nm}$ wide carbon tubes (Figures S20G-H). TEM images further revealed that the bigger particles were encapsulated in thicker graphitized carbons, for example, $8 \mathrm{~nm}$ versus $15 \mathrm{~nm}$ in thickness were observed for samples NC@Co and NC@Mn ${ }_{4} \mathrm{~N}-\mathrm{CoC}_{x}$, respectively (Figures S20C, F). According to the EDX elemental mapping studies (Figure S21), the distributions of $\mathrm{Mn}$ and $\mathrm{N}$ in sample $\mathrm{NC@Mn}{ }_{4} \mathrm{~N}-\mathrm{CoC}_{\mathrm{x}}$ overlapped each other, indicating a rather strong interaction between $\mathrm{Mn}$ and $\mathrm{N}$. These observations were consistent with the results obtained from XRD and Raman spectroscopy, which overall suggested that $\mathrm{Mn}$ promoted the formation of graphitized carbons while Mo hindered this phenomenon. Nevertheless, the composited Mo helped in controlling the coalescence of the Co-based nanoparticles during the sintering process, which could be attributed to the improved thermal stability of the MF resin after interacting with the molybdic acid [86]. Consequently, the smaller nanoparticles encapsulated with thinner carbon layers could be generated from $\mathrm{Mn}$-Co oxide nanoparticles coated with molybdic-acid-bridged MF resin, which would then possibly lead to a superior distribution of active sites on the surface of the $\mathrm{Mo}_{2} \mathrm{C}$ NC@Mn-Co/CoO material.

The pore characteristics of these samples were further analyzed by $\mathrm{N}_{2}$ adsorption-desorption measurements. These studies proved that the sample $\mathrm{Mo}_{2} \mathrm{C}-\mathrm{NC} @ \mathrm{Mn}-\mathrm{Co} / \mathrm{CoO}$ exhibited a favorable mesoporous structure with the highest surface area. The $\mathrm{N}_{2}$ sorption isotherms (Figures S22A-B) for samples $\mathrm{Mo}_{2} \mathrm{C}-\mathrm{NC} @ \mathrm{Mn}-\mathrm{Co}$ and $\mathrm{Mo}_{2} \mathrm{C}-\mathrm{NC} @ \mathrm{Co} / \mathrm{CoO}$ were close to the $\mathrm{H}_{3}$ hysteresis loop, suggesting that the pores due to the stacking of the particles were mainly formed in these materials. Similar hysteresis loops observed in the $\mathrm{N}_{2}$ sorption isotherms of samples NC@Co and 
$\mathrm{NC@Mn}{ }_{4} \mathrm{~N}-\mathrm{CoC}_{\mathrm{x}}$ (Figures S22C-D) could be attributed to the stacking of carbon tubes. According to the $\mathrm{BJH}$ method [87], the pores of sample $\mathrm{Mo}_{2} \mathrm{C}-\mathrm{NC} @ \mathrm{Mn}-\mathrm{Co} / \mathrm{CoO}$ (Figure S23A) were mainly distributed with a width of less than $30 \mathrm{~nm}$ with the highest peak at about $8 \mathrm{~nm}$, indicating that this material had a mesoporous structure. A well-defined peak at around $9 \mathrm{~nm}$ was displayed in the pore width distribution of sample $\mathrm{Mo}_{2} \mathrm{C}-\mathrm{NC} @ \mathrm{Co} / \mathrm{CoO}$ (Figure S23B), as per the porous structure originated from the stacking of the nanoparticles. These mesoporous structures are important for the mass transports during electrochemical reactions and can therefore improve the reactions to some extent [88-90]. The carbon nanotubes encapsulated with big particles in samples NC@Co and $\mathrm{NC@Mn}{ }_{4} \mathrm{~N}-\mathrm{CoC}_{\mathrm{x}}$ offered a wider pore distribution beyond 50 nm (Figures S23C-D). The control sample showed an even larger pore width distribution (Figure S24B). Moreover, the Brunauer-Emmett-Teller (BET) surface area of the $\mathrm{Mo}_{2} \mathrm{C}-\mathrm{NC} @ \mathrm{Mn}$-Co/CoO material was $606 \mathrm{~m}^{2} \mathrm{~g}^{-1}$, much larger than that of the samples Mo $2 \mathrm{C}-\mathrm{NC} @ \mathrm{Co} / \mathrm{CoO}\left(309 \mathrm{~m}^{2} \mathrm{~g}^{-1}\right.$ ), NC@Co (352 $\left.\mathrm{m}^{2} \mathrm{~g}^{-1}\right)$, and $\mathrm{NC@Mn}{ }_{4} \mathrm{~N}-\mathrm{CoC}_{\mathrm{x}}\left(95 \mathrm{~m}^{2} \mathrm{~g}^{-1}\right)$. In general, a larger surface area supports more active sites on the surface of the catalysts, which is one of the main contributing factors in improving the activity of the electrochemical catalysts.

The surface contents and species were further investigated by XPS studies (Figure 4), even though the spectra were dominated by the carbon peak. The overall spectra of the sample $\mathrm{Mo}_{2} \mathrm{C}-$ $\mathrm{NC@Mn-Co/CoO}$ are presented in Figure S25, indicating that it mainly contained carbon and elemental Co, Mn, Mo, N, and O on the surface.
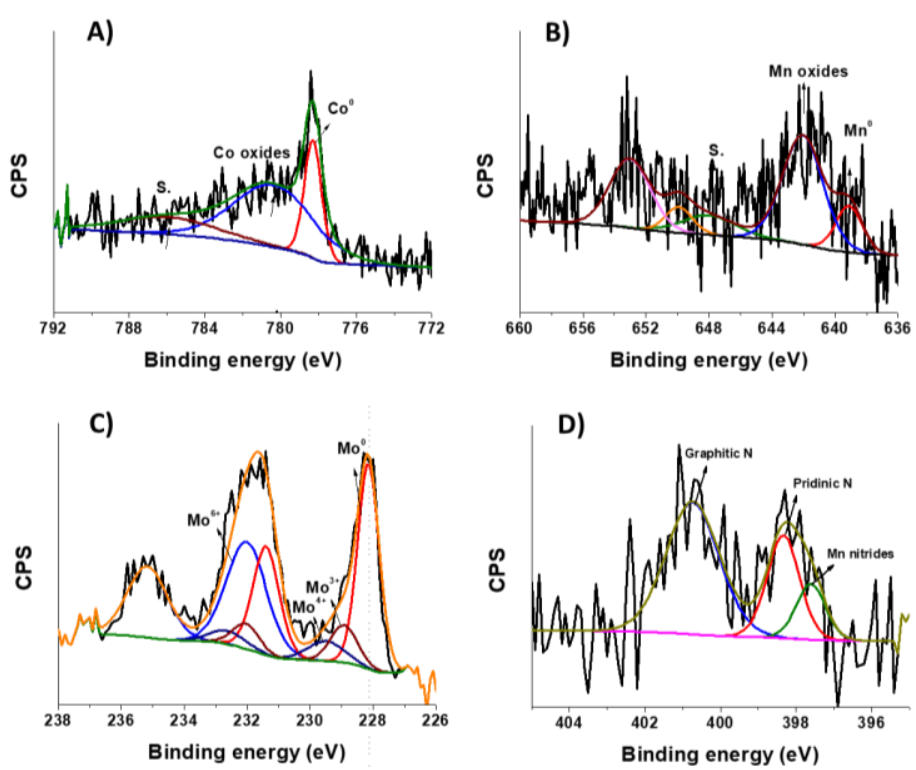

Figure 4 The individual XPS spectra for A) Co 2p, B) Mn 2p, C) Mo 3p, and D) N1s in sample $\mathrm{Mo}_{2} \mathrm{C}-\mathrm{NC} @ \mathrm{Mn}-\mathrm{Co} / \mathrm{CoO}$.

The $\mathrm{Co}_{2} \mathrm{p}$ XPS spectrum of the sample $\mathrm{Mo}_{2} \mathrm{C}-\mathrm{NC} @ \mathrm{Mn}-\mathrm{Co} / \mathrm{CoO}$ (Figure 4A) showed that the Co surface mainly consisted of oxidized Co (roughly $75 \pm 5 \% \mathrm{Co}_{2}{ }^{+}$or $\mathrm{Co}^{3+}$; signal at around $780.4 \mathrm{eV}$ and a hardly visible satellite peak at $786.00 \mathrm{eV}$, which would indicate $\mathrm{CoO}$ as the main Co-oxide) and additional metallic Co (roughly $25 \pm 5 \%$; signals at around $778.3 \mathrm{eV}$ ). These findings were also consistent with the XRD results. The presence of both metallic $\mathrm{Co}$ and $\mathrm{CoO}$ in this sample was promising since both are potentially active for ORR and OER $[44,47,75]$. Similarly, the Mn2p XPS spectrum (Figure $4 \mathrm{~B}$ ) revealed the presence of oxidized $\mathrm{Mn}$ (roughly $85 \pm 5 \%$; signal at $641.8 \mathrm{eV}$ ) 
and metallic $\mathrm{Mn}$ (signal at $638.7 \mathrm{eV}$ ). The $\mathrm{Mn}$ surface species most likely originated from the $\mathrm{Mn}$ doping of the Co species, which could further promote the electronic modification of the active sites [28, 84, 91]. The Mo3d spectrum of sample $\mathrm{Mo}_{2} \mathrm{C}-\mathrm{NC} @ \mathrm{Mn}-\mathrm{Co} / \mathrm{CoO}$ (Figure 4C) indicated four different oxidation states of $\mathrm{Mo}\left(\mathrm{MoO}, \mathrm{Mo}^{3+}, \mathrm{Mo}^{4+}\right.$, and $\left.\mathrm{Mo}^{6+}\right)$. The fitting peaks of $\mathrm{Mo}^{0}$ and $\mathrm{Mo}^{3+}$ were related to the Mo-Mo and Mo-C bonds of the Mo carbides on the surface [92]. These Mo carbide surface species can act as ORR active sites to improve the OER activity of the composited Co species [93-95]. The presence of higher oxidation states $\left(\mathrm{Mo}^{4+}\right.$ and $\left.\mathrm{Mo}^{6+}\right)$, which accounted for roughly $45 \%$ of $\mathrm{Mo}$ at the surface, revealed the existence of $\mathrm{Mo}$ oxides $\left(\mathrm{MoO}_{2}\right.$ and $\left.\mathrm{MoO}_{3}\right)$, insignificant for the electrochemical reactions due to their poor stability and conductivity [96]. The N1s XPS spectrum (Figure 4D) showed three peaks located at $400.7 \mathrm{eV}, 398.3 \mathrm{eV}$, and $397.6 \mathrm{eV}$, assigned to graphitic $\mathrm{N}$, pyridinic $\mathrm{N}$, and metal nitrides, respectively. Pyridinic and graphitic $\mathrm{N}$ are known to promote the mass diffusion and adsorption of the electrolyte due to the presence of a coordinatively active electron lone pair [68]. The metal nitrides observed at around $397.6 \mathrm{eV} \mathrm{might}$ indicate the presence of $\mathrm{Mn}$ nitrides as reported previously [97]; however, these results did not represent a clear experimental proof. Metal- $\mathrm{N}$ sites are intrinsically active for the ORR and could work as a pre-catalyst for OER by transforming into metal-O intermediates during the electrochemical process $[29,98,99]$.

\subsection{Electrocatalytic Evaluation of the Hybrid Materials}

The electrocatalytic performance of the as-prepared materials for both ORR and OER was investigated by measuring polarization profiles with a three-electrode system in $0.1 \mathrm{M} \mathrm{KOH}$ electrolyte. The evaluations were then compared with commercial precious $\mathrm{Pt}-\mathrm{C}$ and $\mathrm{RuO}_{2}$ catalysts. The CV graph (Figure S27A) of $\mathrm{Mo}_{2} \mathrm{C}-\mathrm{NC} @ \mathrm{Mn}-\mathrm{Co} / \mathrm{CoO}$ was measured in $\mathrm{O}_{2}$-saturated 0.1 $\mathrm{M} \mathrm{KOH}$, which revealed a peak at $0.76 \mathrm{~V}$. This signal, however, disappeared while measuring the $\mathrm{CV}$ graph under the same conditions in Ar-saturated 0.1 M KOH (Figure S27B), hence confirming that the material was active for $\mathrm{O}_{2}$ reduction. The signal value was not only larger than other samples (0.71-0.73 V; Figures S28A-E), it was also comparable to Pt-C (0.78 V; Figure S28F). As shown in Figure 5A, the sample $\mathrm{Mo}_{2} \mathrm{C}-\mathrm{NC} @ \mathrm{Mn}-\mathrm{Co} / \mathrm{CoO}$ showed an overpotential of $0.82 \mathrm{~V}$ at a current density of $3 \mathrm{~mA} \mathrm{~cm}{ }^{-2}$ at a rotating speed of $1600 \mathrm{rpm}$ and a scan rate of $5 \mathrm{mV} \mathrm{s}^{-1}$,

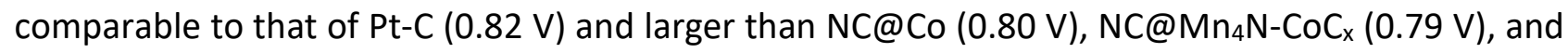
$\mathrm{Mo} 2 \mathrm{C}-\mathrm{NC} @ \mathrm{Co}(0.75 \mathrm{~V})$. These findings indicated the high intrinsic ORR activity of the sample $\mathrm{Mo}_{2} \mathrm{C}$ $\mathrm{NC@Mn-Co/CoO}$. In contrast, the Mn doping in the sample NC@Mn ${ }_{4} \mathrm{~N}-\mathrm{CoC}_{x}$ failed to offer a higher ORR activity. Based on these findings, we conclude that the $\mathrm{Mn}$ component was not the main factor for the superior ORR activity. Moreover, the trend observed for these samples agreed with the binding energies of the surface carbons, which confirmed the positive effect of the defected carbons and $\mathrm{Co}$ oxide on the ORR reaction of $\mathrm{Mo}_{2} \mathrm{C}-\mathrm{NC} @ \mathrm{Mn}$-Co. In addition, the diffusion-limiting current density (5.63 mA cm${ }^{-2}$ ) of $\mathrm{Mo}_{2} \mathrm{C}-\mathrm{NC} @ \mathrm{Mn}$-Co was also larger than those observed in the case of NC@Mn 4 N-CoC $\left(5.25\right.$ mA cm$\left.{ }^{-2}\right)$, NC@Co (4.88 mA cm$\left.{ }^{-2}\right), \mathrm{Mo}_{2} \mathrm{C}-\mathrm{NC} @ \mathrm{Co}\left(4.41 \mathrm{~mA} \mathrm{~cm}^{-2}\right)$, and $\mathrm{Pt}-\mathrm{C}\left(5.05 \mathrm{~mA} \mathrm{~cm}{ }^{-2}\right.$ ). This suggested that $\mathrm{Mo}_{2} \mathrm{C}-\mathrm{NC} @ \mathrm{Mn}-\mathrm{Co} / \mathrm{CoO}$ had a remarkable mass-charge transport capacity, which could be attributed to its mesoporous structure and superior conductivity likely enhanced by the presence of carbon nanotubes. To further investigate the kinetics of this material for ORR, the polarization curves at a rotating speed of 400-2400 rpm were recorded (Figure S29A). In the potential range of 0.1-0.7 V, the presented platforms revealed that 
the ORR current over the sample $\mathrm{Mo}_{2} \mathrm{C}-\mathrm{NC} @ \mathrm{Mn}-\mathrm{Co} / \mathrm{CoO}$ was fully limited by mass diffusion. Based on the linear fittings of the Koutecky-Levich (K-L) plots (Figure 29B), the number of electrons transferred during the ORR reaction was calculated to be 3.4-3.7, indicating that the $\mathrm{O}_{2}$ reduction over the $\mathrm{Mo}_{2} \mathrm{C}-\mathrm{NC} @ \mathrm{Co} / \mathrm{Mn} / \mathrm{CoO}$ mainly involved a four-electron transfer process, which also commonly occurs over the Pt-C catalysts.

A)
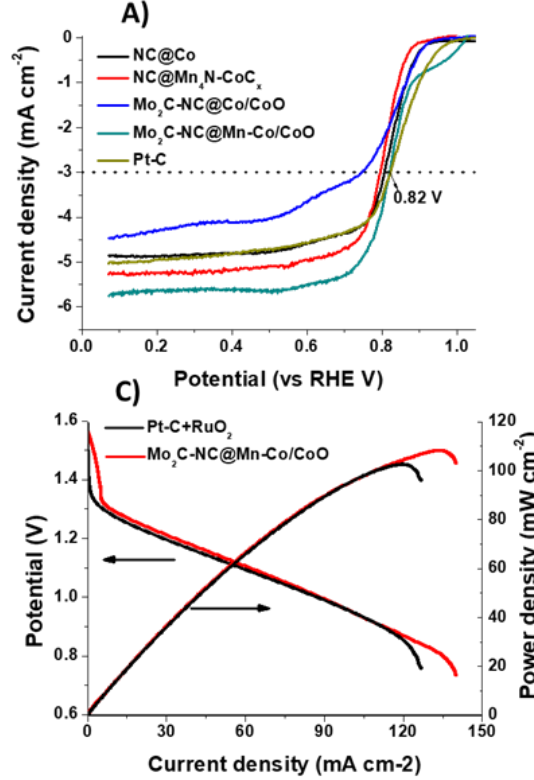

E)

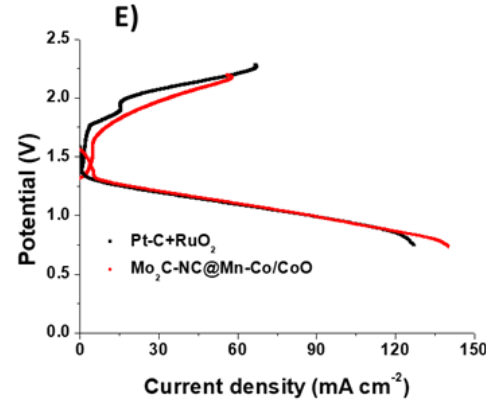

B)

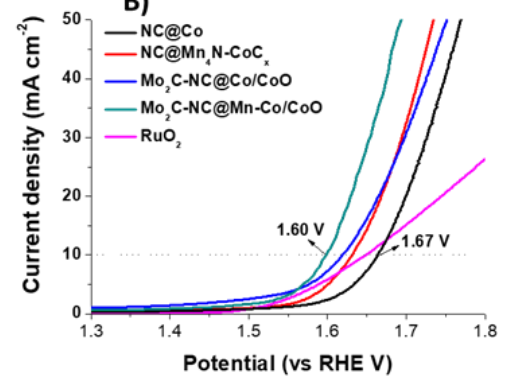

D)
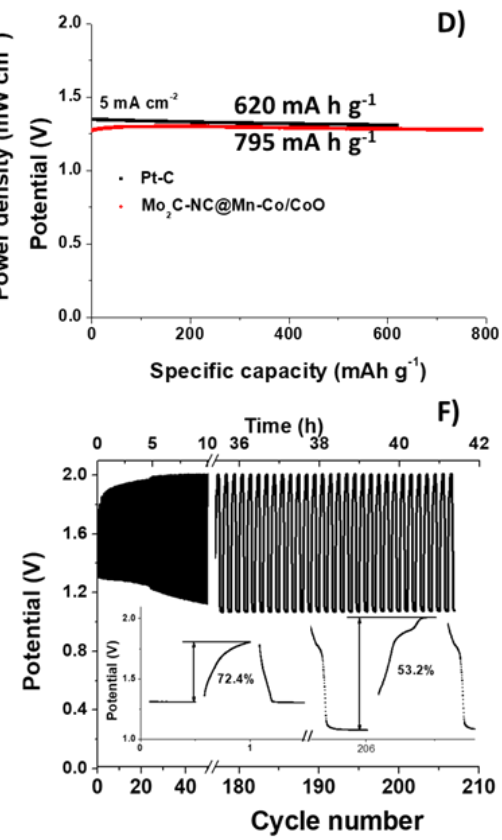

Figure 5 A) The ORR and B) OER polarization curves of different samples measured at a rotating speed of $1600 \mathrm{rpm}$ and a scan rate of $5 \mathrm{mV} \mathrm{s}^{-1}$ in $0.1 \mathrm{M} \mathrm{KOH}$. C) The discharge polarization curves and the related powder density graphs, D) the discharge curves at a constant current density of $5 \mathrm{~mA} \mathrm{~cm}^{-2}$, and $\mathrm{E}$ ) the charge and discharge graphs of the $\mathrm{Zn}$-air batteries, respectively driven by the $\mathrm{Mo}_{2} \mathrm{C}-\mathrm{NC} @ \mathrm{Mn}-\mathrm{Co} / \mathrm{CoO}$ and $\mathrm{Pt}-\mathrm{C}+\mathrm{RuO} 2$ catalyst in $6.0 \mathrm{M} \mathrm{KOH} / 0.2 \mathrm{M} \mathrm{Zn}(\mathrm{OAc})_{2}$. F) The cyclic measurement of the $\mathrm{Zn}$-air battery driven by the $\mathrm{Mo}_{2} \mathrm{C}-\mathrm{NC} @ \mathrm{Mn}-\mathrm{Co} / \mathrm{CoO}$ catalyst in $6 \mathrm{M} \mathrm{KOH} / 0.2 \mathrm{M} \mathrm{Zn(OAc)}$.

The $\mathrm{Mo}_{2} \mathrm{C}-\mathrm{NC} @ \mathrm{Mn}-\mathrm{Co} / \mathrm{CoO}$ material also appeared as an outstanding catalyst for OER, as shown in Figure 5B. It exhibited a lower overpotential and a higher current density than the other samples over the measured potential range in $0.1 \mathrm{M} \mathrm{KOH}$. At a current density of $10 \mathrm{~mA} \mathrm{~cm}^{-2}$, it showed an overpotential of 0.37 V, lower than NC@Co (0.44 V), NC@Mn ${ }_{4} \mathrm{~N}-\mathrm{CoC}_{\mathrm{x}}(0.40 \mathrm{~V}), \mathrm{Mo}_{2} \mathrm{C}-$ $\mathrm{NC} @ \mathrm{Co} / \mathrm{CoO}(0.39 \mathrm{~V})$, and even $\mathrm{RuO}_{2}(0.42 \mathrm{~V})$. Based on the lower overpotential and higher

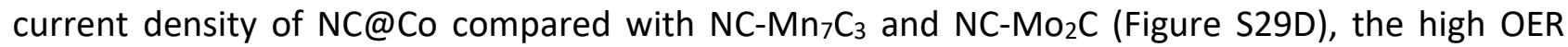
activity of the sample $\mathrm{Mo}_{2} \mathrm{C}-\mathrm{NC} @ \mathrm{Mn}-\mathrm{Co} / \mathrm{CoO}$ could be attributed to the intrinsic OER activity of 
Co-based species [24]. Since the OER overpotential of $\mathrm{NC@Mn}{ }_{4} \mathrm{~N}-\mathrm{CoC}_{\mathrm{x}}$ was smaller compared to NC@Co, we assumed that the Mn doping or the formation of Mn nitrides on the surface promoted the OER reaction. Furthermore, the high surface area and favorable mesoporous structure of the sample $\mathrm{Mo}_{2} \mathrm{C}-\mathrm{NC} @ \mathrm{Mn}-\mathrm{Co} / \mathrm{CoO}$ could further promote the dispersion and accessibility of the active sites on the surface. As shown by the quadrangle-shaped CV graph of the highest area in the range of 1.2--1.4 V (Figure S30A), the sample $\mathrm{Mo}_{2} \mathrm{C}-\mathrm{NC} @ M n-\mathrm{Co} / \mathrm{CoO}$ had the largest double-layer capacitance. According to a linear fitting of the current density at a constant potential of $1.35 \mathrm{~V}$ at various scan rates (20--140 mVs ${ }^{-1}$ ), $\mathrm{Mo}_{2} \mathrm{C}-\mathrm{NC} @ \mathrm{Mn}-\mathrm{Co} / \mathrm{CoO}$ also had the highest electrochemical surface area $\left(603 \mathrm{~m}^{2} \mathrm{~g}^{-1}\right)$, comparable to its BET surface area $\left(606 \mathrm{~m}^{2} \mathrm{~g}^{-1}\right.$ ) (Figures S30B-C). Based on the electrochemical impedance spectroscopy (EIS) at an open circuit potential in $6 \mathrm{M} \mathrm{KOH}$ (Figure S30D), the sample $\mathrm{Mo}_{2} \mathrm{C}-\mathrm{NC} @ \mathrm{Mn}-\mathrm{Co} / \mathrm{CoO}$ exhibited the most vertical low-frequency line of the Nyquist plot, hence indicating fast ion diffusion and transport in it. These findings suggested that the mesoporous structure of the sample $\mathrm{Mo}_{2} \mathrm{C}-\mathrm{NC} @ \mathrm{Mn}-\mathrm{Co} / \mathrm{CoO}$ improved the ion diffusion transport from the electrolyte to the surface-active sites. As a result, this optimized porous structure favored both ORR and OER reactions over the $\mathrm{Mo}_{2} \mathrm{C}-\mathrm{NC} @ \mathrm{Mn}-\mathrm{Co} / \mathrm{CoO}$ material. The longterm stability of the sample $\mathrm{Mo}_{2} \mathrm{C}-\mathrm{NC} @ \mathrm{Mn}-\mathrm{Co} / \mathrm{CoO}$ was also studied. The studies revealed that this sample could preserve about $89 \%$ ORR current and $85 \%$ OER current after $10000 \mathrm{~s}$ of ORR and OER processes in a basic electrolyte (Figure S31). These values were greater than the values over Pt-C (80\%) and $\mathrm{RuO}_{2}(41 \%)$. The reversible oxygen electrode property could be evaluated by the potential difference between OER and ORR, namely, $\Delta E=E_{j}=10-E_{j}=3$, where $E_{j}=10$ is the operating OER potential at $10 \mathrm{~mA} \mathrm{~cm}$ and $E_{j}=3$ is the ORR potential at $3 \mathrm{~mA} \mathrm{~cm}^{-2}$. From this relation, the calculated value of $\Delta \mathrm{E}$ for the sample $\mathrm{Mo}_{2} \mathrm{C}-\mathrm{NC} @ \mathrm{Mn}-\mathrm{Co} / \mathrm{CoO}$ was equal to $0.78 \mathrm{~V}$, lower than the other evaluated samples, including the precious catalysts $\left(0.83 \mathrm{~V}, \mathrm{Pt}-\mathrm{C} / / \mathrm{RuO}_{2}\right)$ as shown in Table S3. Also, this value was comparable to state-of-the-art materials (Table S4), including Ni-MnO/rGO aerogel (0.82 V) [24], Co-N-CNTs (0.79 V) [100], and Ni3Fe/N-C (0.84 V) [23], hence showcasing the outstanding reversible oxygen electrode property of $\mathrm{Mo}_{2} \mathrm{C}-\mathrm{NC} @ \mathrm{Mn}-\mathrm{Co} / \mathrm{CoO}$.

Considering the superior bifunctional performance of the $\mathrm{Mo}_{2} \mathrm{C}-\mathrm{NC} @ \mathrm{Mn}-\mathrm{Co} / \mathrm{CoO}$ material prepared herein and the recently reported promising properties of $\mathrm{CoO}_{x} / \mathrm{CoN}_{\mathrm{y}}$ nanoparticles encapsulated carbon-nitride nanosheets as efficient trifunctional electrocatalyst for overall water splitting and Zn-air battery [100], a home-made Zn-air battery was built to evaluate its feasibility in practical energy devices. The material was first loaded on a nickel foam, which was then pressed together with a carbon paper to be applied as the air cathode. A polished $\mathrm{Zn}$ plate and $6.0 \mathrm{M}$ $\mathrm{KOH} / 0.2 \mathrm{M} \mathrm{Zn}(\mathrm{OAc})_{2}$ solution were employed as the anode and electrolyte of the $\mathrm{Zn}$-air battery, respectively. For comparison, a commercial precious $\mathrm{Pt}-\mathrm{C}+\mathrm{RuO}_{2}$ catalyst with a $1 / 1$ mass ratio of $\mathrm{Pt}-\mathrm{C}$ to $\mathrm{RuO}_{2}$ was used as the air cathode for the control battery. As shown in Figure $5 \mathrm{C}$, the calculated peak power density of the $\mathrm{Zn}$-air battery driven by the $\mathrm{Mo}_{2} \mathrm{C}-\mathrm{NC} @ \mathrm{Mn}-\mathrm{Co} / \mathrm{CoO}$ catalyst was equal to $108 \mathrm{mWcm}^{-2}$, exceeding the value of the Pt-C $+\mathrm{RuO}_{2}$ catalyst-driven battery (103 $\mathrm{mWcm}^{-2}$ ). Furthermore, the specific capacities of these two $\mathrm{Zn}$-air batteries were measured from the consumption of $\mathrm{Zn}$ based on the discharge at a rate of $5 \mathrm{mAcm}^{-2}$. It was observed that the $\mathrm{Mo}_{2} \mathrm{C}-\mathrm{NC} @ \mathrm{Mn}-\mathrm{Co} / \mathrm{CoO}$ catalyst could drive the $\mathrm{Zn}$-air battery with a specific capacity of 795 mAhgzn $^{-1}$, which was about $97 \%$ utilization of the theoretical capacity (Figure 5D). Moreover, the battery exhibited a high energy density of $1025 \mathrm{Whkgz}^{-1}$, about $94 \%$ of the theoretical energy density. These values outperformed the battery, driven by the Pt-C $+\mathrm{RuO}_{2}$ catalyst (specific capacity of $620 \mathrm{mAhg}_{\mathrm{zn}}{ }^{-1}$, energy density of $818 \mathrm{Whkg}_{\mathrm{zn}}{ }^{-1}$ ), and were even comparable to the high- 
end catalysts such as Ni-MnO/rGO aerogel (758 mAhgzn ${ }^{-1}$ ) [24], MOF-derived Co@N-C (751 $\left.\mathrm{mAhg}_{z \mathrm{n}}{ }^{-1}\right)$ [101], and $\mathrm{Ni}_{3} \mathrm{Fe} / \mathrm{N}-\mathrm{C}\left(528 \mathrm{mAhg}_{\mathrm{Zn}}{ }^{-1}\right.$ ) [23], reported so far (Table S7). The charge and discharge polarization curves of these two Zn-air batteries are shown in Figure 5E. The Zn-air battery driven by the $\mathrm{Mo}_{2} \mathrm{C}-\mathrm{NC} @ \mathrm{Mn}-\mathrm{Co} / \mathrm{CoO}$ catalyst showed similar charge-discharge behavior as that of the one driven by the high-performing $\mathrm{Pt}-\mathrm{C}+\mathrm{RuO}_{2}$ catalyst, hence indicating its outstanding rechargeability. To further evaluate the stability of the devices, the batteries were cycled at a current density of $5 \mathrm{mAcm}^{-2}$, with each cycle running $10 \mathrm{~min}$ longer. After 206 cycles, the voltaic efficiency of the $\mathrm{Mo}_{2} \mathrm{C}-\mathrm{NC} @ \mathrm{Mn}-\mathrm{Co} / \mathrm{CoO}$ driven battery was about $53.2 \%$, which was about $72.4 \%$ of the first cycle (Figure $5 \mathrm{~F}$ ), while that of the $\mathrm{Pt}-\mathrm{C}+\mathrm{RuO}_{2}$ catalyst-driven battery were $67 \%$ ( $1^{\text {st }}$ cycle) and $48.2 \%$ (158 ${ }^{\text {th }}$ cycle) (Figure S32). In summary, the Zn-air battery driven by Mo $2 \mathrm{C}-\mathrm{NC} @ \mathrm{Mn}-\mathrm{Co} / \mathrm{CoO}$ catalyst exhibited a higher voltaic efficiency during the cyclic process, which proved the long-term stability of the corresponding material. Overall, the $\mathrm{Mo}_{2} \mathrm{C}-\mathrm{NC} @ \mathrm{Mn}$ $\mathrm{Co} / \mathrm{CoO}$ material appeared as a promising material for their application in $\mathrm{Zn}$-air batteries with high efficiency and good stability.

The decay of the voltaic efficiencies could be attributed to the compositional changes in the catalyst materials, change of the electrolyte and zinc electrode, and the isolation of catalyst materials from the electrode may further deteriorate the efficiency of the $\mathrm{Zn}$ air battery during measurement as previously reported [102]. During our experiment, we observed a change in the electrolyte solution, which turned to a white suspension most likely due to the reactions of the hydroxide anions with atmospheric $\mathrm{CO}_{2}$, along with the formation of a small amount of black powder during the long-term measurements. Moreover, the polished zinc electrode turned out to be rather rough, and it is well known that crystal branches can grow on the surface of the zinc electrode during the recharging process.

\section{Conclusion}

In summary, we reported a one-pot synthesis of the $\mathrm{Mo}_{2} \mathrm{C}-\mathrm{NC} @ \mathrm{Mn}-\mathrm{Co} / \mathrm{CoO}$ composite material, which was found to be highly active for both ORR and OER reactions while showing remarkable long-term durability. The superior performance was attributed to the optimized mesoporous structure and suitable combined compositions of the $\mathrm{Mo}_{2} \mathrm{C}-\mathrm{NC} @ \mathrm{Mn}-\mathrm{Co} / \mathrm{CoO}$ material. The molybdic acid-bridged MF resin hindered the aggregation of the $\mathrm{Mn}$-Co-based nanoparticles by improving the decomposition temperature of the composite precursor, while the CA-treated melamine inhibited their coalescence during the sintering process. As a result, the small-sized nanoparticles were formed, thereby promoting the formation of mesopores and the dispersion of metal-based components. The graphitized carbons in the $\mathrm{Mo}_{2} \mathrm{C}-\mathrm{NC} @ \mathrm{Mn}-\mathrm{Co} / \mathrm{CoO}$ material were co-activated by $\mathrm{Mn}$ and Mo. The growth of the graphitized carbons was assisted by $\mathrm{Mn}$ doping of the composite material, while the formation of $\mathrm{Mo}_{2} \mathrm{C}$ resulted in defect-rich carbon materials. Our study demonstrated that $\mathrm{Mo}_{2} \mathrm{C}-\mathrm{NC} @ \mathrm{Mn}-\mathrm{Co} / \mathrm{CoO}$ promoted the dispersion of active sites and supported the mass/electron transfer reactions. Conclusively, $\mathrm{Mo}_{2} \mathrm{C}-\mathrm{NC} @ \mathrm{Mn}-\mathrm{Co} / \mathrm{CoO}$ emerged as a highly efficient electrocatalyst for both the ORR and OER reactions due to its low potential gap, hence rendering it a promising catalyst for the air electrode of a $\mathrm{Zn}$-air battery. The catalytic activity of the $\mathrm{Mo}_{2} \mathrm{C}-\mathrm{NC} @ \mathrm{Mn}-\mathrm{Co} / \mathrm{CoO}$ material in the ORR reaction was improved due to the $\mathrm{N}$ doping and the presence of defect-rich carbon materials and Co-based components ( $\mathrm{Co} / \mathrm{CoO}$ ), whereas Mn-doping had no beneficial effect on the ORR activity, and the surface Mo oxides were 
even disadvantageous for these reactions. In contrast, the OER activity was mainly improved by the presence of the Co-based species and $\mathrm{Mn}$ doping or the formation of $\mathrm{Mn}$ nitrides on the surface. Although $\mathrm{Mo}_{2} \mathrm{C}$ is known to be an effective substance for hydrogen evolution reaction (HER), it offers a weak catalytic activity for ORR and OER [103].

\section{Experimental Section}

\subsection{Synthesis of $\mathrm{Mo}_{2} \mathrm{C}-\mathrm{NC} @ M n-\mathrm{Co} / \mathrm{CoO}$ Material}

Sample E was prepared by the following method: Mn-Co oxide nanoparticles were synthesized upon thermal treatment of a solution of $0.3 \mathrm{mmol} \mathrm{Mn}(\mathrm{III})$ acetylacetonate $\left(\mathrm{Mn}(\mathrm{AcAc})_{3}\right)$ and 2.75 mmol Co(ACAC) $)_{2}$ in $12 \mathrm{~mL}$ oleic acid (OLA) at $250{ }^{\circ} \mathrm{C}$ for $1 \mathrm{~h}$. The so-formedMn-Co oxide nanoparticles were precipitated by adding $10 \mathrm{~mL}$ of ethanol, isolated by centrifugation, and then purified by repeated washing (three times) with dichloromethane (DCM) and ethanol (10 $\mathrm{mL}$ ). The $\mathrm{Mn}$-Co oxide nanoparticles were then redispersed in $10 \mathrm{~mL}$ of ethanol, dissolved by the addition of $1 \mathrm{mmol}$ (192 mg) of citric acid (CA), and sonicated at ambient temperature for $15 \mathrm{~min}$. After the addition of $8 \mathrm{~mL}$ of ethanol and $2 \mathrm{~mL}$ of $\mathrm{H}_{2} \mathrm{O}$, the resulting mixture was transferred into an autoclave reactor. $0.45 \mathrm{mmol}$ of molybdic acid $(77 \mathrm{mg}), 1.5 \mathrm{mmol}$ of melamine $(189 \mathrm{mg})$, and 0.6 $\mathrm{mL}$ of formaldehyde solution (36-37\% wt.\%; $6 \mathrm{mmol}$ ) were then added, and the solution was stirred at ambient temperature for $30 \mathrm{~min}$ and then heated to $150{ }^{\circ} \mathrm{C}$ for $16 \mathrm{~h}$, finally yielding the molybdic acid-bridged MF polymer $\mathrm{Mn}$-Co oxide composite precursor. After centrifugation and drying, the precursor was mixed with $2.5 \mathrm{~g}$ of CA-treated melamine $(\mathrm{CM})$ and calcined at $800{ }^{\circ} \mathrm{C}$ for $1 \mathrm{~h}$ at a heating rate of $5{ }^{\circ} \mathrm{C} / \mathrm{min}$ under Ar flow. The preparation of CA-treated melamine is mentioned in the supporting information. Other samples were synthesized by the same procedure using different amounts of metal sources as summarized in Table S1 of the supporting information.

\subsection{Synthesis of the Control Sample}

$0.45 \mathrm{mmol}(80 \mathrm{mg}$ ) ammonium molybdate, $2.75 \mathrm{mmol} \mathrm{Co}(\mathrm{II})$ acetate tetrahydrate (686 mg), and $0.3 \mathrm{mmol} \mathrm{Mn}(\mathrm{II})$ acetate tetrahydrate $\left(74 \mathrm{mg}\right.$ ) were dissolved in $30 \mathrm{~mL}$ of $\mathrm{H}_{2} \mathrm{O} .2 .5 \mathrm{~g}$ of CAtreated melamine was added to the above mixture, and the solution was sonicated for $10 \mathrm{~min}$. After removing all the volatiles in a vacuum at $80^{\circ} \mathrm{C}$, a solid mixture was obtained, which was then used to prepare the control sample by the thermal treatment at $800^{\circ} \mathrm{C}$ for $1 \mathrm{~h}$ under Ar flow.

Characterization. The materials were analyzed by powder X-ray diffraction (PXRD) using a Bruker D8 Advance Discover X-ray diffractometer with a $\mathrm{Cu}$ Ka radiation. Transmission electron microscopy (TEM) and scanning electron microscopy (SEM) were performed with a JEM-2200 FS microscope and an ESEM Quanta 400 FEG microscope, respectively. Energy dispersive X-ray (EDX) elemental mappings were conducted using a JEM-2200FS microscope. A surface area and pore size analyzer (NOVA 3000e instrument) was used to record the $\mathrm{N}_{2}$ adsorption and desorption isotherms. Raman spectroscopic studies were performed with a Renishaw InVia Raman microscope to analyze the graphitic structures, while the metal composition (Co, Mn) of the materials were determined using a SOLAAR M Series AA Spectrometer. The Mo contents were measured by UV-vis spectroscopy by using a Varian Cary 300 UV-Vis instrument (SI). C, H, and N analyses were obtained with a EURO EA Elemental Analyzer. APHI VersaProbe II Scanning XPS Microprobe instrument was employed to analyze the surface species. The structure of the 
precursor composite was analyzed by Fourier-transform infrared spectroscopy (FTIR) using a Bruker ATR Spectrometer, while the thermal behavior of the precursors was analyzed with a TGA/DSC1 STAR system.

\subsection{Electrochemical Evaluation}

Both the oxygen evolution reaction (OER) and oxygen reduction reaction (ORR) were evaluated using a three-electrode system of Metrohm Autolab with Nova software. $3 \mathrm{mg}$ of finely ground materials were dispersed in a solution of $100 \mu \mathrm{L}$ of $\mathrm{H}_{2} \mathrm{O}, 195 \mu \mathrm{L}$ of EtOH, and $25 \mu \mathrm{L}$ of Nafion, and sonicated at ambient temperature for $1 \mathrm{~h}$. $15 \mu \mathrm{L}$ of the resulting ink was then dropped on a rotating disc of glassy carbon (GC) electrode to reach a loading amount of $0.72 \mathrm{mgcm}^{-2}$, which was then used as the working electrode after drying in the oven at $60{ }^{\circ} \mathrm{C}$. A platinum sheet and an $\mathrm{Ag} / \mathrm{AgCl}$ electrode treated with a $3.5 \mathrm{M} \mathrm{KCl}$ solution were used as the control electrode and reference electrode, respectively. The $\mathrm{CV}$ graphs were measured at a rotating speed of $1600 \mathrm{rpm}$ with a scan rate of $50 \mathrm{mVs}^{-1}$ in $\mathrm{O}_{2}$-saturated $0.1 \mathrm{M} \mathrm{KOH}$ solution. The polarization profiles of ORR were tested at a rotating speed of $1600 \mathrm{rpm}$ and a scan rate of $5 \mathrm{mVs}^{-1}$ in $\mathrm{O}_{2}$-saturated $0.1 \mathrm{M} \mathrm{KOH}$ solution. The profiles were corrected by taking recordings in an Ar-saturated electrolyte. The polarization curves of the OER were obtained at a rotating speed of $1600 \mathrm{rpm}$ and a scan rate of 5 $\mathrm{mVs}^{-1}$ in Ar-saturated $0.1 \mathrm{M} \mathrm{KOH}$ solution. For comparison, the polarization curves of Pt-C (0.1 $\left.\mathrm{mgcm}^{-2}\right)$ and $\mathrm{RuO}_{2}\left(0.24 \mathrm{mg} \mathrm{cm}{ }^{-2}\right)$ were also recorded for ORR and OER. To study the mass transport properties of the materials, electrochemical impedance spectra (EIS) were recorded in a $6 \mathrm{M} \mathrm{KOH}$ solution at an open circuit potential ( ${ }^{\circ} \mathrm{CP}$ ) with an amplitude of $5 \mathrm{mV}$. Furthermore, the cyclic voltammograms were recorded at different scan rates $\left(20--140 \mathrm{mVs}^{-1}\right)$ with a material loading of $0.24 \mathrm{mgcm}^{-2}$ to calculate the electrochemical surface area (ESCA). All the applied potentials were referred to the reversible hydrogen electrode (RHE) by transforming with the following equation:

$$
\mathrm{E}(\mathrm{vs} \mathrm{RHE})=\mathrm{E}(\mathrm{Ag} / \mathrm{AgCl})+0.204+0.0592 \mathrm{pH}
$$

The kinetic parameters of the ORR of the best sample were evaluated from the K-L equations (Eqs. a-c) [104]:

$$
\begin{gathered}
\frac{1}{J}=\frac{1}{J_{L}}+\frac{1}{J_{K}}=\frac{1}{B \omega^{\frac{1}{2}}}+\frac{1}{J_{K}} \\
B=0.62 n F C_{o} D_{o}^{\frac{2}{3}} v^{-\frac{1}{6}} \\
J_{K}=n F k C_{o}
\end{gathered}
$$

where $J, J_{K}$, and $J_{L}$ are the measured current density, kinetic current density, and diffusion-limiting current density, respectively, while $\omega$ is the angular velocity of the disk, $n$ is the number of electrons transferred during the ORR, $F$ is the Faraday constant $\left(96485 \mathrm{C} \mathrm{mol}^{-1}\right), C_{o}$ is the $\mathrm{O}_{2}$ bulk solubility, $D_{o}$ is the $\mathrm{O}_{2}$ diffusion coefficient, $v$ is the kinematic viscosity of the electrolyte, and $K$ is the electron transfer rate constant. Generally, $C_{o}$ is equal to $1.2 \times 10^{-3} \mathrm{~mol} \mathrm{~L}^{-1}, D_{o}$ is equal to $1.9 \times$ 
$10^{-5} \mathrm{~cm} \mathrm{~s}^{-1}$ and $u$ is taken as $0.01 \mathrm{~cm}^{2} \mathrm{~s}^{-1}$ in a $0.1 \mathrm{M} \mathrm{KOH}$ electrolyte. The values of $n$ and $J_{K}$ were obtained from the slope and intercept of the K-L plots.

The performance of the $\mathrm{Mo}_{2} \mathrm{C}-\mathrm{NC} @ \mathrm{Mn}-\mathrm{Co} / \mathrm{CoO}$ material as an air-electrode catalyst for a $\mathrm{Zn}$-air battery was investigated with an in-house two-electrode cell. A fine polished and cleaned $\mathrm{Zn}$ plate was used as the $\mathrm{Zn}$ electrode, while a nickel foam with a surface area of $1 \mathrm{~cm}^{2}$ containing $10 \mathrm{mg}$ of $\mathrm{Mo}_{2} \mathrm{C}-\mathrm{NC} @ \mathrm{Mn}-\mathrm{Co} / \mathrm{CoO}$ was applied as the air electrode. The two electrodes were pressed together with a hydrophobic carbon paper employed as a gas diffusion layer (GDL). To isolate these two electrodes, a Celgard hydrophilic membrane was used while assembling the battery. The obtained $\mathrm{Zn}$-air battery was then evaluated in a $6 \mathrm{M} \mathrm{KOH}$ electrolyte with $0.2 \mathrm{M} \mathrm{Zn(OAc})_{2}$. For comparison, a nickel foam with a loading of $5 \mathrm{mg}$ of commercial $20 \mathrm{wt} . \% \mathrm{Pt}-\mathrm{C}$ and $5 \mathrm{mg}$ of $\mathrm{RuO}_{2}$ was also evaluated as air electrode. The Zn-air battery was fabricated and measured under ambient conditions. Galvanostatic cycling and polarization graphs of the as-prepared batteries were recorded via Metrohm Autolab.

\section{Acknowledgments}

Financial support by the University of Essen is acknowledged. S.W. is grateful to the Humbold Foundation for a Postdoctoral fellowship. We also like to thank the DFG core facility ICAN (Interdisciplinary Center for Analytics on the Nanoscale) for TEM and XPS studies and Dr. Hagemann (ICAN) for help with the interpretation of XPS spectra.

\section{Author Contributions}

Shiping Wang performed the experimental studies and contributed to the writing of the manuscript. Georg Bendt performed analytical studies (PXRD) and contributed to the writing of the manuscript. Stephan Schulz supervised the work and prepared the final version of the manuscript.

\section{Competing Interests}

The authors have declared that no competing interests exist.

\section{Additional Materials}

The following additional materials are uploaded at the page of this paper.

1. Experimental part 1 (E1)

2. Experimental part 1 (E2)

3. Table S1: The synthesis parameters of different samples.

4. Table S2: The bulk contents of different elements in various samples.

5. Table S3: Differing potential $(\triangle E)$ between the OER potential $\left(E_{O E R}\right)$ at $10 \mathrm{mAcm}^{-2}$ and the ORR potential (EORR) at $-3 \mathrm{mAcm}^{-2}$ for different samples.

6. Table S4: Comparison of the electrochemical performance of $\mathrm{Mo}_{2} \mathrm{C}-\mathrm{NC} @ \mathrm{Mn}-\mathrm{Co} / \mathrm{CoO}$ (this work) with known bifunctional TMs catalysts for OER (EOER) at $10 \mathrm{mAcm}^{-2}$ and ORR (EORR) at -3 $\mathrm{mAcm}^{-2}$ in $0.1 \mathrm{M} \mathrm{KOH}$ electrolyte. 
7. Table S5: Comparison of the specific capacity of the Zn-air battery driven by the $\mathrm{Mo}_{2} \mathrm{CNC} @ \mathrm{Mn}-\mathrm{Co} / \mathrm{CoO}$ material and recently reported bifunctional TMs catalysts in $6 \mathrm{M} \mathrm{KOH} / 0.2$ $M$ zinc salts.

8. Figure S1: TGA (A) and DTG graphs (B) of different precursors.

9. Figure S2: X-ray diffractograms of $\mathrm{Mn}$-doped $\mathrm{CoO}$ nanoparticles and the composite precursor.

10. Figure S3: The FTIR spectra of (A) molybdic acid, (B) melamine-formaldehyde (MF) resin, (C) MF resin-molybdic acid composite, and (D) the composite precursor of molybdic acid bridged MF resin with $\mathrm{Mn}$-Co oxide and the evaporated precursor.

11. Scheme S1: Illustration of the melamine-formaldehyde (MF) resin.

12. Figure S4: TEM images of the $\mathrm{Mn}$-doped $\mathrm{CoO}$ nanoparticles $(\mathbf{A}, \mathbf{B})$ and the melamineformaldehyde resin composited $\mathrm{Mn}$-doped $\mathrm{CoO}$ nanoparticles precursor (C, D).

13. Figure S5: STEM and elemental images of the melamine-formaldehyde resin composited $\mathrm{Mn}$-doped $\mathrm{CoO}$ nanoparticle precursor.

14. Figure S6: SEM (A-B) and width distributions for carbon nanotubes (C) and HR-TEM images (D-E) of the sample E (Mo2 $\mathrm{C}-\mathrm{NC} @ M n-\mathrm{Co} / \mathrm{CoO}(\mathrm{D}-\mathrm{E})$.

15. Figure S7: $\mathrm{N}_{2}$ adsorption-desorption isotherm (A) of sample $E\left(\mathrm{Mo}_{2} \mathrm{C}-\mathrm{NC} @ M n-\mathrm{Co} / \mathrm{CoO}\right)$ and its pore width distribution calculated by the BJH method from the adsorption isotherm (B).

16. Figure S8: XRD patterns of the original precursor of molybdic acid-bridged MF resin-coated $\mathrm{Mn}$-Co oxide nanoparticles and its heated product at $500{ }^{\circ} \mathrm{C}$ (sample $\mathrm{H}$ ), and that of the samples $\mathrm{E}$ $\mathrm{G}$ that were prepared from the calcination of the original precursor mixed with acid-treated melamine at different temperatures.

17. Figure S9: TEM images of the metal/MF resin coordination polymer precursor $(A)$, sample $F$ prepared at $500{ }^{\circ} \mathrm{C}(\mathrm{B}, \mathrm{C})$, sample $\mathrm{G}$ prepared at $650{ }^{\circ} \mathrm{C}(\mathrm{D}-\mathrm{G})$, and sample $\mathrm{E}$ prepared at $800{ }^{\circ} \mathrm{C}(\mathrm{H}$, l).

18. Figure S10: STEM image (A) and elemental mappings (B-G) of the compound prepared from the calcination of the mixture of metal/MF coordination polymer precursor and citric acid-treated melamine at $650{ }^{\circ} \mathrm{C}$ (sample G). The relative elemental contents obtained by the EDX analysis $(\mathbf{H})$ equipped with the TEM instrument.

19. Figure S11: TEM images of the products prepared by calcinating the metal/MF coordination polymer precursor at $500{ }^{\circ} \mathrm{C}$ (sample H; A, B) and $800^{\circ} \mathrm{C}$ (sample I; C, D). STEM image (E) and EDX elemental mappings $(\mathbf{F}, \mathbf{H})$ of sample $\mathbf{I}$.

20. Figure S12: SEM (A, B) and TEM images (C, D) of the $\mathrm{N}$-doped carbon prepared from citric acid-treated melamine.

21. Figure S13: TEM (A, B) and STEM images (C) and corresponding EDX elemental mappings of sample $\mathrm{K}$ prepared from the calcination of a solid mixture precursor at $500{ }^{\circ} \mathrm{C}$ (Mix-500).

22. Figure S14: XRD patterns of the product of sample $\mathrm{K}$ (Mix-500) compared with sample $F$ (CM-Pre-500)

23. Figure S15: TEM images of sample $\mathrm{E}\left(\mathrm{Mo}_{2} \mathrm{C}-\mathrm{NC} @ \mathrm{Mn}-\mathrm{Co} / \mathrm{CoO}\right)(\mathrm{A})$ and the products prepared by calcinating a solid mixture precursor at $800{ }^{\circ} \mathrm{C}$ (control sample; B-D).

24. Figure S16: STEM image and elemental mappings of the control sample prepared from a solid mixture precursor without the HTC composited procedure.

25. Figure S17: XRD patterns of the control sample (M) prepared at $800^{\circ} \mathrm{C}$ from a solid mixture precursor and $\mathrm{Mo}_{2} \mathrm{C}-\mathrm{NC} @ \mathrm{Mn}-\mathrm{Co} / \mathrm{CoO}$ of sample E. 
26. Figure S18: SEM (A, B) and TEM images (C-E) of sample D ( $\left.\mathrm{Mo}_{2} \mathrm{C}-\mathrm{NC} @ \mathrm{Co} / \mathrm{CoO}\right)$ and its particle size distribution graph (F).

27. Figure S19: STEM image and elemental mappings of the $\mathrm{Mo}_{2} \mathrm{C}-\mathrm{NC} @ \mathrm{Co} / \mathrm{CoO}$ material for sample D.

28. Figure S20: SEM (A) and TEM images (B, C) of sample A (NC@Co). SEM (D) and TEM images (E, F) of sample $\mathrm{C}\left(\mathrm{NC@Mn}{ }_{4} \mathrm{~N}-\mathrm{CoC}_{\mathrm{x}}\right)$. Width distributions of the carbon tubes for the samples $\mathrm{NC} @ \mathrm{Co}_{(\mathrm{G}) \text { and NC@Mn}} \mathrm{N}-\mathrm{CoC}_{\mathrm{x}}(\mathrm{H})$.

29. Figure S21: STEM image and EDX elemental mappings of the $N C @ M n_{4} N-C o C_{x}$ material for sample C.

30. Figure S22: $\mathrm{N}_{2}$ adsorption-desorption isotherms of $\mathrm{Mo}_{2} \mathrm{C}-\mathrm{NC} @ M n-\mathrm{Co} / \mathrm{CoO}(\mathbf{A}), \mathrm{Mo}_{2} \mathrm{C}-$ $\mathrm{NC@Co/CoO} \mathrm{(B),} \mathrm{NC@Co} \mathrm{(C),} \mathrm{and} \mathrm{NC@Mn} 4$ N-CoCx (D).

31. Figure S23: Pore width distributions calculated by the $\mathrm{BJH}$ method from the adsorption isotherms of sample $\mathrm{Mo}_{2} \mathrm{C}-\mathrm{NC} @ \mathrm{Mn}-\mathrm{Co} / \mathrm{CoO}$ (A), $\mathrm{Mo}_{2} \mathrm{C}-\mathrm{NC} @ \mathrm{Co} / \mathrm{CoO}$ (B), NC@Co (C), and $\mathrm{NC@Mn}{ }_{4} \mathrm{~N}-\mathrm{CoC}_{\mathrm{x}}$ (D).

32. Figure S24: $\mathrm{N}_{2}$ sorption isotherm (A) and the related pore width distribution (B) of the product from the control sample. The inset is the pore width distribution of sample $\mathrm{Mo}_{2} \mathrm{C}$ $\mathrm{NC@Mn-Co/CoO.}$

33. Figure S25: The overall XPS spectrum of sample $\mathrm{E}\left(\mathrm{Mo}_{2} \mathrm{C}-\mathrm{NC} @ \mathrm{Mn}-\mathrm{Co} / \mathrm{CoO}\right)$.

34. Figure S26: The Mo3p XPS spectra of $\mathrm{Mo}_{2} \mathrm{C}-\mathrm{NC} @ M n-\mathrm{Co} / \mathrm{CoO}$ and $\mathrm{Mo}_{2} \mathrm{C}-\mathrm{NC} @ \mathrm{Co} / \mathrm{CoO}(\mathrm{A})$. O1s XPS spectra (B), Co 2 p XPS spectra (C), and C1s XPS spectra (D) of different samples.

35. Figure S27: The ORR CV graphs of 20 wt.\% Pt-C and $\mathrm{Mo}_{2} \mathrm{C}-\mathrm{NC} @ M n-\mathrm{Co} / \mathrm{CoO}$ at a $1600 \mathrm{rpm}$ and a scan rate of $50 \mathrm{mVs}^{-1}$ in $0.1 \mathrm{M} \mathrm{KOH}$ in the $\mathrm{O}_{2}$ flow $(\mathbf{A}, \mathbf{C})$ and $\mathrm{Ar}$ flow $(\mathbf{B}, \mathbf{D})$, respectively.

36. Figure S28: The CV graphs for the ORR measurement of different materials at $1600 \mathrm{rpm}$ and a scan rate of $50 \mathrm{mVs}^{-1}$ in $0.1 \mathrm{M} \mathrm{KOH}$.

37. Figure S29: ORR polarization curves of sample $\mathrm{Mo}_{2} \mathrm{C}-\mathrm{NC} @ \mathrm{Mn}-\mathrm{Co} / \mathrm{CoO}$ measured at a rotating speed of $400--2400 \mathrm{rpm}$ and a scan rate of $5 \mathrm{mVs}^{-1}$ (A). K-L plots for the sample $\mathrm{Mo}_{2} \mathrm{CNC} @ \mathrm{Mn}-\mathrm{Co} / \mathrm{CoO}$ at the ORR potential of 0.1-0.7 V (B). ORR (C) and OER polarization curves (D) of these samples with sole metal source. ORR (E) and OER polarization curves (F) of the sample Mo2 $\mathrm{C}-\mathrm{NC} @ \mathrm{Mn}-\mathrm{Co} / \mathrm{CoO}$ compared with the control sample.

38. Figure S30: CV graphs of different samples at a scan rate of $100 \mathrm{mVs}^{-1}$ in $0.1 \mathrm{M} \mathrm{KOH} \mathrm{(A).} \mathrm{CV}$ graphs of sample $\mathrm{Mo}_{2} \mathrm{C}-\mathrm{NC} @ \mathrm{Mn}-\mathrm{Co} / \mathrm{CoO}$ at $20-140 \mathrm{mVs}^{-1}$ in $0.1 \mathrm{M} \mathrm{KOH}$ (B). The variation of the current density at $1.35 \mathrm{~V}$ vs RHE with the increase in the scan rates for the CV of different samples (C). The electrochemical impedance spectra recorded at the open circuit potential over the frequency range of $100 \mathrm{kHz}$ to $0.1 \mathrm{~Hz}$ with an amplitude of $5 \mathrm{mV}$ in $6 \mathrm{M} \mathrm{KOH}$ (D).

39. Figure S31: The time-dependent curve of ORR current density at a constant potential of 0.7 $\checkmark$ vs RHE in $0.1 \mathrm{M} \mathrm{KOH} \mathrm{(A).} \mathrm{The} \mathrm{time-dependent} \mathrm{curve} \mathrm{of} \mathrm{OER} \mathrm{current} \mathrm{density} \mathrm{at} \mathrm{a} \mathrm{constant}$ potential to reach an original current density of $10 \mathrm{mAcm}^{-2}$ in $0.1 \mathrm{M} \mathrm{KOH} \mathrm{(B).}$

40. Figure S32: The cyclic measurement of the $\mathrm{Zn}$-air battery driven by the $\mathrm{Pt}-\mathrm{C}+\mathrm{RuO}_{2}$ catalyst.

\section{References}

1. Steele BC, Heinzel A. Materials for fuel cell technologies. Nature. 2001; 414: 345-352.

2. Van Mierlo J, Maggetto G. Fuel cell or battery: Electric cars are the future. Fuel Cells. 2007; 7 : 165-173. 
3. Dresselhaus MS, Thomas IL. Alternative energy technologies. Nature. 2001; 414: 332-337.

4. Armand M, Tarascon JM. Building better batteries. Nature. 2008; 451: 652-657.

5. Shao $M$, Chang $Q$, Dodelet JP, Chenitz R. Recent advances in electrocatalysts for oxygen reduction reaction. Chem Rev. 2016; 116: 3594-3657.

6. Suntivich J, Gasteiger HA, Yabuuchi N, Nakanishi H, Goodenough JB, Shao-Horn Y. Design principles for oxygen-reduction activity on perovskite oxide catalysts for fuel cells and metalair batteries. Nat Chem. 2011; 3: 546-550.

7. Davari E, Ivey DG. Bifunctional electrocatalysts for Zn-air batteries. Sustain Energy Fuels. 2018; 2: 39-67.

8. Li YG, Dai HJ. Recent advances in zinc-air batteries. Chem Soc Rev. 2014; 43: 5257-5275.

9. Cheng FY, Chen J. Metal-air batteries: From oxygen reduction electrochemistry to cathode catalysts. Chem Soc Rev. 2012; 41: 2172-2192.

10. Debe MK. Electrocatalyst approaches and challenges for automotive fuel cells. Nature. 2012; 486: 43-51.

11. Nørskov JK, Rossmeisl J, Logadottir A, Lindqvist L, Kitchin JR, Bligaard T, et al. Origin of the overpotential for oxygen reduction at a fuel-cell cathode. J Phys Chem B. 2004; 108: 1788617892.

12. Nie Y, Li L, Wei ZD. Recent advancements in Pt and Pt-free catalysts for oxygen reduction reaction. Chem Soc Rev. 2015; 44: 2168-2201.

13. Zhang CL, Hwang SY, Trout A, Peng ZM. Solid-state chemistry-enabled scalable production of octahedral Pt-Ni alloy electrocatalyst for oxygen reduction reaction. J Am Chem Soc. 2014; 136 : 7805-7808.

14. Seitz LC, Dickens CF, Nishio K, Hikita Y, Montoya J, Doyle A, et al. A highly active and stable $\mathrm{IrO}_{x} \mathrm{SrIrO}_{3}$ catalyst for the oxygen evolution reaction. Science. 2016; 353: 1011-1014.

15. Lee Y, Suntivich J, May KJ, Perry EE, Shao-Horn Y. Synthesis and activities of rutile $\mathrm{IrO}_{2}$ and $\mathrm{RuO}_{2}$ nanoparticles for oxygen evolution in acid and alkaline solutions. J Phys Chem Lett. 2012; 3: 399-404.

16. Chen ZW, Higgins D, Yu AP, Zhang L, Zhang JJ. A review on non-precious metal electrocatalysts for PEM fuel cells. Energy Environ Sci. 2011; 4: 3167-3192.

17. Zhang HG, Hwang S, Wang MY, Feng ZX, Karakalos S, Luo LL, et al. Single atomic iron catalysts for oxygen reduction in acidic media: Particle size control and thermal activation. J Am Chem Soc. 2017; 139: 14143-14149.

18. Wang MQ, Ye C, Wang M, Li TH, Yu YN, Bao SJ. Synthesis of $M\left(\mathrm{Fe}_{3} \mathrm{C}, \mathrm{Co}, \mathrm{Ni}\right)$-porous carbon frameworks as high-efficient ORR catalysts. Energy Stor Mater. 2018; 11: 112-117.

19. Suntivich J, May KJ, Gasteiger HA, Goodenough JB, Shao-Horn Y. A perovskite oxide optimized for oxygen evolution catalysis from molecular orbital principles. Science. 2011; 334: 1383-1385.

20. Subbaraman R, Tripkovic D, Chang KC, Strmcnik D, Paulikas AP, Hirunsit $P$, et al. Trends in activity for the water electrolyser reactions on $3 \mathrm{~d} M(\mathrm{Ni}, \mathrm{Co}, \mathrm{Fe}, \mathrm{Mn})$ hydr(oxy)oxide catalysts. Nat Mater. 2012; 11: 550-557.

21. McCrory CC, Jung S, Peters JC, Jaramillo TF. Benchmarking heterogeneous electrocatalysts for the oxygen evolution reaction. J Am Chem Soc. 2013; 135: 16977-16987.

22. Bajdich M, Garcia-Mota M, Vojvodic A, Norskov JK, Bell AT. Theoretical investigation of the activity of cobalt oxides for the electrochemical oxidation of water. J Am Chem Soc. 2013; 135: 13521-13530. 
23. Fu GT, Cui ZM, Chen YF, Li YT, Tang YW, Goodenough JB. Ni $\mathrm{Ni}_{3} \mathrm{Fe}-\mathrm{N}$ doped carbon sheets as a bifunctional electrocatalyst for air cathodes. Adv Energy Mater. 2017; 7: 1601172.

24. Fu GT, Yan XX, Chen YF, Xu L, Sun DM, Lee JM, et al. Boosting bifunctional oxygen electrocatalysis with 3D graphene aerogel-supported Ni/MnO particles. Adv Mater. 2018; 30: 1704609.

25. Li YJ, Cui L, Da PF, Qiu KW, Qin WJ, Hu WB, et al. Multiscale structural engineering of Ni-doped CoO nanosheets for Zinc-air batteries with high power density. Adv Mater. 2018; 30: e1804653.

26. Wang TT, Kou ZK, Mu SC, Liu JP, He DP, Amiinu IS, et al. 2D dual-metal zeolitic-imidazolateframework-(ZIF)-derived bifunctional air electrodes with ultrahigh electrochemical properties for rechargeable Zinc-air batteries. Adv Funct Mater. 2018; 28: 1705048.

27. Wei L, Karahan HE, Zhai SL, Liu HW, Chen XC, Zhou Z, et al. Amorphous bimetallic oxidegraphene hybrids as bifunctional oxygen electrocatalysts for rechargeable $\mathrm{Zn}$-air batteries. Adv Mater. 2017; 29: 1701410.

28. Zhao AQ, Masa J, Xia W, Maljusch A, Willinger MG, Clavel G, et al. Spinel Mn-Co oxide in Ndoped carbon nanotubes as a bifunctional electrocatalyst synthesized by oxidative cutting. J Am Chem Soc. 2014; 136: 7551-7554.

29. Li Y, Kuttiyiel KA, Wu LJ, Zhu YM, Fujita E, Adzic RR, et al. Enhancing electrocatalytic performance of bifunctional cobalt-manganese-oxynitride nanocatalysts on graphene. ChemSusChem. 2017; 10: 68-73.

30. Gorlin Y, Jaramillo TF. A bifunctional nonprecious metal catalyst for oxygen reduction and water oxidation. J Am Chem Soc. 2010; 132: 13612-13614.

31. Tan $\mathrm{P}$, Chen $\mathrm{B}, \mathrm{Xu} \mathrm{HR}$, Cai WZ, He W, Liu ML, et al. $\mathrm{Co}_{3} \mathrm{O}_{4}$ nanosheets as active material for hybrid Zn batteries. Small. 2018; 14: 1800225.

32. Zhong YT, Pan ZH, Wang XS, Yang J, Qiu YC, Xu SY, et al. Hierarchical $\mathrm{Co}_{3} \mathrm{O}_{4}$ nano-micro arrays featuring superior activity as cathode in a flexible and rechargeable Zinc-air battery. Adv Sci. 2019; 6: 1802243.

33. Liu MS, Chen T, Zhang WX, Wei S, Cheng YJ, Liu JQ. In situ construction of pollen-petal-like heterostructured $\mathrm{CO}_{3} \mathrm{O}_{4}-\mathrm{CeO}_{2}$ on $3 \mathrm{D} \mathrm{FeNi}$ foam as a bifunctional catalyst for overall water splitting. Sustain Energy Fuels. 2021; 5: 2181-2189.

34. Li JJ, Zhou HL, Jian ZX, Li HL, Guan XG, Xing YL, et al. Improved electrocatalytic activity of threedimensional open-structured $\mathrm{Co}_{3} \mathrm{O}_{4} @ \mathrm{MnO}_{2}$ bifunctional catalysts of $\mathrm{Li}_{2} \mathrm{O}_{2}$ batteries by inducing the oriented growth of $\mathrm{Li}_{2} \mathrm{O}_{2}$. ACS Sustain Chem Eng. 2021; 9: 5334-5344.

35. Liang YY, Wang HL, Zhou JG, Li YG, Wang J, Regier T, et al. Covalent hybrid of spinel manganese-cobalt oxide and graphene as advanced oxygen reduction electrocatalysts. J Am Chem Soc. 2012; 134: 3517-3523.

36. Fosdick SE, Berglund SP, Mullins CB, Crooks RM. Evaluating electrocatalysts for the hydrogen evolution reaction using bipolar electrode arrays: $\mathrm{Bi}$ - and trimetallic combinations of $\mathrm{Co}, \mathrm{Fe}, \mathrm{Ni}$, Mo, and W. ACS catalysis. 2014; 4: 1332-1339.

37. Zhang B, Zheng XL, Voznyy O, Comin R, Bajdich M, García-Melchor M, et al. Homogeneously dispersed multimetal oxygen-evolving catalysts. Science. 2016; 352: 333-337.

38. Zheng XL, Zhang B, De Luna P, Liang YF, Comin R, Voznyy O, et al. Theory-driven design of highvalence metal sites for water oxidation confirmed using in situ soft X-ray absorption. Nat Chem. 2018; 10: 149-154.

39. Wu X, Tang CJ, Cheng Y, Min XB, Jiang SP, Wang SY. Bifunctional catalysts for reversible oxygen 
evolution reaction and oxygen reduction reaction. Chem A Eur J. 2020; 26: 3906-3929.

40. Chung HT, Won JH, Zelenay P. Active and stable carbon nanotube/nanoparticle composite electrocatalyst for oxygen reduction. Nat Commun. 2013; 4: 1-5.

41. Wu ZS, Yang SB, Sun Y, Parvez K, Feng XL, Mullen K. 3D nitrogen-doped graphene aerogelsupported $\mathrm{Fe}_{3} \mathrm{O}_{4}$ nanoparticles as efficient electrocatalysts for the oxygen reduction reaction. J Am Chem Soc. 2012; 134: 9082-9085.

42. Wu G, More KL, Johnston CM, Zelenay P. High-performance electrocatalysts for oxygen reduction derived from polyaniline, iron, and cobalt. Science. 2011; 332: 443-447.

43. Wang SP, Wang J, Zhu ML, Bao XB, Xiao BY, Su DF, et al. Molybdenum-carbide-modified nitrogen-doped carbon vesicle encapsulating nickel nanoparticles: A highly efficient, low-cost catalyst for hydrogen evolution reaction. J Am Chem Soc. 2015; 137: 15753-15759.

44. Liang YY, Wang HL, Diao P, Chang W, Hong GS, Li YG, et al. Oxygen reduction electrocatalyst based on strongly coupled cobalt oxide nanocrystals and carbon nanotubes. J Am Chem Soc. 2012; 134: 15849-15857.

45. Li YG, Gong M, Liang YY, Feng J, Kim JE, Wang HL, et al. Advanced zinc-air batteries based on high-performance hybrid electrocatalysts. Nat Commun. 2013; 4: 1-7.

46. Lefèvre $M$, Proietti $E$, Jaouen $F$, Dodelet JP. Iron-based catalysts with improved oxygen reduction activity in polymer electrolyte fuel cells. Science. 2009; 324: 71-74.

47. Jin HY, Wang J, Su DF, Wei ZZ, Pang ZF, Wang Y. In situ cobalt-cobalt oxide/N-doped carbon hybrids as superior bifunctional electrocatalysts for hydrogen and oxygen evolution. J Am Chem Soc. 2015; 137: 2688-2694.

48. Huang X, Qi XY, Boey F, Zhang H. Graphene-based composites. Chem Soc Rev. 2012; 41: 666686.

49. Wan WJ, Liu XJ, Li HY, Peng $X Y, X i$ DS, Luo J. 3D carbon framework-supported CoNi nanoparticles as bifunctional oxygen electrocatalyst for rechargeable $\mathrm{Zn}$-air batteries. Appl Catal B Environ. 2019; 240: 193-200.

50. Li HY, Zhang LH, Li L, Wu CW, Huo YJ, Chen Y, et al. Two-in-one solution using insect wings to produce graphene-graphite films for efficient electrocatalysis. Nano Res. 2019; 12: 33-39.

51. Gao SS, Liu YF, Xie ZY, Qiu Y, Zhuo LC, Qin YJ, et al. Metal-free bifunctional ordered mesoporous carbon for reversible $\mathrm{Zn}-\mathrm{CO}_{2}$ batteries. Small Methods. 2021; 5: 2001039.

52. Xu J, Lai SH, Qi DF, Hu M, Peng XY, Liu YF, et al. Atomic Fe-Zn dual-metal sites for high-efficiency pH-universal oxygen reduction catalysis. Nano Res. 2021; 14: 1374-1381.

53. Zhang L, Li L, Chen HM, Wei ZD. Recent progress in precious metal-free carbon-based materials towards the oxygen reduction reaction: Activity, stability, and anti-poisoning. Chem A Eur J. 2020; 26: 3973-3990.

54. Yan XC, Jia Y, Yao XD. Defects on carbons for electrocatalytic oxygen reduction. Chem Soc Rev. 2018; 47: 7628

55. Yan XC, Jia Y, Chen J, Zhu ZH, Yao XD. Defective-activated-carbon-supported Mn-Co nanoparticles as a highly efficient electrocatalyst for oxygen reduction. Adv Mater. 2016; 28: 8771-8778.

56. Jia Y, Zhang LZ, Du AJ, Gao GP, Chen J, Yan XC, et al. Defect graphene as a trifunctional catalyst for electrochemical reactions. Adv Mater. 2016; 28: 9532-9538.

57. Lu XF, Chen Y, Wang SB, Gao SY, Lou XW. Interfacing manganese oxide and cobalt in porous graphitic carbon polyhedrons boosts oxygen electrocatalysis for $\mathrm{Zn}$-air batteries. Adv Mater. 
2019; 31: 1902339.

58. Li SS, Hao XG, Abudula A, Guan GQ. Nanostructured Co-based bifunctional electrocatalysts for energy conversion and storage: Current status and perspectives. J Mater Chem A. 2019; 7: 18674-18707.

59. Sun YT, Liu XR, Jiang YM, Li J, Ding J, Hu WB, et al. Recent advances and challenges in divalent and multivalent metal electrodes for metal-air batteries. J Mater Chem A. 2019; 7: 1818318208.

60. Deng J, Wang L, Jin F, Hu YH. Metal-free surface-microporous graphene electrocatalysts from $\mathrm{CO}_{2}$ for rechargeable all-solid-state zinc-air batteries. J Mater Chem A. 2021; 9: 10081-10087.

61. Zhang J, Zhou QX, Tang YW, Zhang L, Li YG. Zinc-air batteries: Are they ready for prime time? Chem Sci. 2019; 10: 8924-8929.

62. Zhu XF, Hu CG, Amal R, Dai LM, Lu XY. Heteroatom-doped carbon catalysts for zinc-air batteries: Progress, mechanism, and opportunities. Energy Environ Sci. 2020; 13: 4536-4563.

63. Lei CS, Zhou W, Feng QG, Lei YP, Zhang Y, Chen Y, et al. Charge engineering of $\mathrm{Mo}_{2} \mathrm{C} @$ defectrich $\mathrm{N}$-doped carbon nanosheets for efficient electrocatalytic $\mathrm{H}_{2}$ evolution. Nano Micro Lett. 2019; 11: 1-10.

64. Zhang JT, Dai LM. Nitrogen, phosphorus, and fluorine tri-doped graphene as a multifunctional catalyst for self-powered electrochemical water splitting. Angew Chem Int Ed Engl. 2016; 55: 13296-13300.

65. Wan W, Wang Q, Zhang L, Liang HW, Chen P, Yu SH. N-, P- and Fe-tridoped nanoporous carbon derived from plant biomass: An excellent oxygen reduction electrocatalyst for zinc-air batteries. J Mater Chem A. 2016; 4: 8602-8609.

66. Wu G, Mack NH, Gao W, Ma SG, Zhong RQ, Han JT, et al. Nitrogen-doped graphene rich catalysts derived from heteroatom polymers for oxygen reduction in nonaqueous lithium $\mathrm{O}_{2}$ battery cathode. ACS Nano. 2012; 6: 9764-9776.

67. Tong Y, Chen PZ, Zhou TP, Xu K, Chu WS, Wu CZ, et al. A bifunctional hybrid electrocatalyst for oxygen reduction and evolution: Cobalt oxide nanoparticles strongly coupled to $\mathrm{B}, \mathrm{N}$-decorated graphene. Angew Chem Int Ed Engl. 2017; 56: 7121-7125.

68. Lee SY, Chung DY, Lee MJ, Kang YS, Shin H, Kim MJ, et al. Charting the outer helmholtz plane and the role of nitrogen doping in the oxygen reduction reaction conducted in alkaline media using nonprecious metal catalysts. J Phys Chem C. 2016; 120: 24511-24520.

69. Iglesias D, Giuliani A, Melchionna M, Marchesan S, Criado A, Nasi L, et al. N-doped graphitized carbon nanohorns as a forefront electrocatalyst in highly selective $\mathrm{O}_{2}$ reduction to $\mathrm{H}_{2} \mathrm{O}_{2}$. Chem. 2018; 4: 106-123.

70. Ding $Y$, Jiang $Y, X u F$, Yin J, Ren $H$, Zhuo $Q$, et al. Preparation of nano-structured $\mathrm{LiFePO}_{4} /$ graphene composites by co-precipitation method. Electrochem Commun. 2010; 12: 10-13.

71. Jin C, Lu FL, Cao XC, Yang ZR, Yang RZ. Facile synthesis and excellent electrochemical properties of $\mathrm{NiCo} 2 \mathrm{O} 4$ spinel nanowire arrays as a bifunctional catalyst for the oxygen reduction and evolution reaction. J Mater Chem A. 2013; 1: 12170-12177.

72. Yan J, Sun W, Wei T, Zhang Q, Fan ZJ, Wei F. Fabrication and electrochemical performances of hierarchical porous $\mathrm{Ni}(\mathrm{OH}) 2$ nanoflakes anchored on graphene sheets. J Mater Chem. 2012; 22: 11494-11502.

73. Tabassum H, Guo W, Meng W, Mahmood A, Zhao R, Wang QF, et al. Metal-organic frameworks 
derived cobalt phosphide architecture encapsulated into B/N Co-doped graphene nanotubes for All pH value electrochemical hydrogen evolution. Adv Energy Mater. 2017; 7: 1601671.

74. Zhang WM, Yao XY, Zhou SN, Li XW, Li L, Yu Z, et al. ZIF-8/ZIF-67-derived Co-Nx -embedded 1D porous carbon nanofibers with graphitic carbon-encased Co nanoparticles as an efficient bifunctional electrocatalyst. Small. 2018; 14: e1800423.

75. Chen BL, Ma GP, Zhu YQ, Xia YD. Metal-organic-frameworks derived cobalt embedded in various carbon structures as bifunctional electrocatalysts for oxygen reduction and evolution reactions. Sci Rep. 2017; 7: 1-9.

76. Khalid $M$, Honorato AM, Varela $H$, Dai LM. Multifunctional electrocatalysts derived from conducting polymer and metal organic framework complexes. Nano Energy. 2018; 45: 127-135.

77. Borghei M, Lehtonen J, Liu L, Rojas OJ. Advanced biomass-derived electrocatalysts for the oxygen reduction reaction. Adv Mater. 2018; 30: e1703691.

78. Qiao M, Tang C, He G, Qiu K, Binions R, Parkin IP, et al. Graphene/nitrogen-doped porous carbon sandwiches for the metal-free oxygen reduction reaction: Conductivity versus active sites. J Mater Chem A. 2016; 4: 12658-12666.

79. Sheng ZH, Shao L, Chen JJ, Bao WJ, Wang FB, Xia XH. Catalyst-free synthesis of nitrogen-doped graphene via thermal annealing graphite oxide with melamine and its excellent electrocatalysis. ACS Nano. 2011; 5: 4350-4358.

80. Li RM, Cao AM, Zhang YJ, Li G, Jiang F, Li SM, et al. Formation of nitrogen-doped mesoporous graphitic carbon with the help of melamine. ACS Appl Mater Interfaces. 2014; 6: 20574-20578.

81. Liao YL, Gao Y, Zhu SM, Zheng JS, Chen ZX, Yin C, et al. Facile fabrication of N-doped graphene as efficient electrocatalyst for oxygen reduction reaction. ACS Appl Mater Interfaces. 2015; 7: 19619-19625.

82. Hu CL, Zhang L, Zhao ZJ, Luo J, Shi J, Huang ZQ, et al. Edge sites with unsaturated coordination on core-shell $\mathrm{Mn}_{3} \mathrm{O}_{4} @ \mathrm{Mn}_{\mathrm{x}} \mathrm{CO}_{3-\mathrm{x}} \mathrm{O}_{4}$ nanostructures for electrocatalytic water oxidation. Adv Mater. 2017; 29: 1701820.

83. Haber JA, Anzenburg E, Yano J, Kisielowski C, Gregoire JM. Multiphase nanostructure of a quinary metal oxide electrocatalyst reveals a new direction for OER electrocatalyst design. Adv Energy Mater. 2015; 5: 1402307.

84. Li J, Wang YC, Zhou T, Zhang H, Sun XH, Tang J, et al. Nanoparticle superlattices as efficient bifunctional electrocatalysts for water splitting. J Am Chem Soc. 2015; 137: 14305-14312.

85. Yan XC, Jia Y, Odedairo T, Zhao XJ, Jin Z, Zhu ZH, et al. Activated carbon becomes active for oxygen reduction and hydrogen evolution reactions. Chem Commun. 2016; 52: 8156-8159.

86. Wang SP, Bendt G, Saddeler S, Schulz S. Synergistic effects of $\mathrm{Mo}_{2} \mathrm{C}-\mathrm{NC} @ \mathrm{Co}_{x} \mathrm{Fe}_{\mathrm{y}}$ core-shell nanoparticles in electrocatalytic overall water splitting reaction. Energy Technol. 2019; 7: 1801121.

87. Luisa Ojeda M, Marcos Esparza J, Campero A, Cordero S, Kornhauser I, Rojas F. On comparing BJH and NLDFT pore-size distributions determined from N2 sorption on SBA-15 substrata. Phys Chem Chem Phys. 2003; 5: 1859-1866.

88. Liang HW, Zhuang XD, Bruller S, Feng XL, Mullen K. Hierarchically porous carbons with optimized nitrogen doping as highly active electrocatalysts for oxygen reduction. Nat Commun. 2014; 5: 1-7.

89. Zhang ZP, Sun JT, Wang F, Dai LM. Efficient oxygen reduction reaction (ORR) catalysts based on single iron atoms dispersed on a hierarchically structured porous carbon framework. Angew 
Chem Int Ed Engl. 2018; 57: 9038-9043.

90. Lee $S$, Choun M, Ye Y, Lee J, Mun Y, Kang E, et al. Designing a highly active metal-free oxygen reduction catalyst in membrane electrode assemblies for alkaline fuel cells: Effects of pore size and doping-site position. Angew Chem Int Ed Engl. 2015; 54: 9230-9234.

91. Yazdani S, Kashfi-Sadabad R, Palmieri A, Mustain WE, Thompson Pettes M. Effect of cobalt alloying on the electrochemical performance of manganese oxide nanoparticles nucleated on multiwalled carbon nanotubes. Nanotechnology. 2017; 28: 155403.

92. Oshikawa K, Nagai $\mathrm{M}$, Omi S. Characterization of molybdenum carbides for methane reforming by TPR, XRD, and XPS. J Phys Chem B 2001; 105: 9124-9131.

93. Jiang J, Liu QX, Zeng CM, Ai LH. Cobalt/molybdenum carbide@N-doped carbon as a bifunctional electrocatalyst for hydrogen and oxygen evolution reactions. J Mater Chem A. 2017; 5: 16929-16935.

94. Kwak WJ, Lau KC, Shin CD, Amine K, Curtiss LA, Sun YK. A Mo 2 C/carbon nanotube composite cathode for lithium-oxygen batteries with high energy efficiency and long cycle life. ACS Nano. 2015; 9: 4129-4137.

95. Regmi YN, Waetzig GR, Duffee KD, Schmuecker SM, Thode JM, Leonard BM. Carbides of group IVA, VA and VIA transition metals as alternative HER and ORR catalysts and support materials. J Mater Chem A. 2015; 3: 10085-10091.

96. Xiang $\mathrm{ML}$, Li DB, Li WH, Zhong $B$, Sun YH. Potassium and nickel doped $\beta-\mathrm{Mo}_{2} \mathrm{C}$ catalysts for mixed alcohols synthesis via syngas. Catal Commun. 2007; 8: 513-518.

97. Guo Z, Zhou LB, Cao HB, Xie YB, Xiao JD, Yang J, et al. $\mathrm{C}_{3} \mathrm{~N}_{4}-\mathrm{Mn} / \mathrm{CNT}$ composite as a heterogeneous catalyst in the electro-peroxone process for promoting the reaction between $\mathrm{O}_{3}$ and $\mathrm{H}_{2} \mathrm{O}_{2}$ in acid solution. Catal Sci Technol. 2018; 8: 6241-6251.

98. Miura A, Rosero-Navarro C, Masubuchi Y, Higuchi M, Kikkawa S, Tadanaga K. Nitrogen-rich manganese oxynitrides with enhanced catalytic activity in the oxygen reduction reaction. Angew Chem Int Ed Engl. 2016; 55: 7963-7967.

99. Rodriguez-Gomez A, Holgado JP, Caballero A. Cobalt carbide identified as catalytic site for the dehydrogenation of ethanol to acetaldehyde. ACS Catal. 2017; 7: 5243-5247.

100.Liu JM, Wang CB, Sun HM, Wang H, Rong FL, He LH, et al. $\mathrm{CoO}_{x} / \mathrm{CoN}_{y}$ nanoparticles encapsulated carbon-nitride nanosheets as an efficiently trifunctional electrocatalyst for overall water splitting and Zn-air battery. Appl Catal B Environ. 2020; 279: 119407.

101.Zhang MD, Dai QB, Zheng HG, Chen MD, Dai LM. Novel MOF-derived Co@N-C bifunctional catalysts for highly efficient Zn-air batteries and water splitting. Adv Mater. 2018; 30: 1705431.

102.Gu P, Zheng MB, Zhao QX, Xiao X, Xue HG, Pang H. Rechargeable zinc-air batteries: A promising way to green energy. J Mater Chem A. 2017; 5: 7651-7666.

103. Reynard D, Nagar B, Girault H. Photonic Flash Synthesis of Mo2C/Graphene Electrocatalyst for the Hydrogen Evolution Reaction. Acs Catalysis. 2021; 11: 5865-5872.

104.Liu RL, Wu DQ, Feng XL, Müllen K. Nitrogen-doped ordered mesoporous graphitic arrays with high electrocatalytic activity for oxygen reduction. Angew Chem. 2010; 122: 2619-2623. 


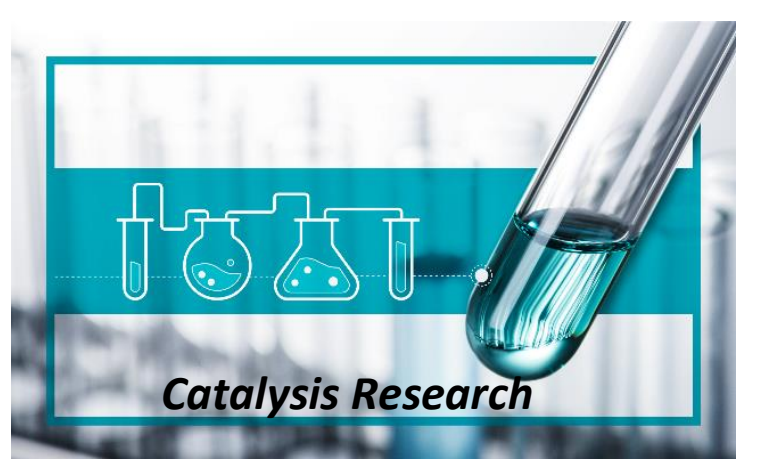

Enjoy Catalysis Research by:

1. Submitting a manuscript

2. Joining in volunteer reviewer bank

3. Joining Editorial Board

4. Guest editing a special issue

For more details, please visit:

http://www.lidsen.com/journals/cr 